\title{
FAZER HISTÓRIA, FAZER SENTIDO: ASSOCIAÇÃO CULTURAL DO NEGRO (1954-1964)*
}

Mário Augusto Medeiros da Silva

As comemorações organizadas em torno da efeméride do IV Centenário da cidade de São Paulo, em 1954, engendraram diferentes eventos e ações, estudados em detalhe por extensa bibliografia (Abud, 1985; Arruda, 2001; Ferreira, 2002; Lofego, 2004) que, entre outros aspectos, se debruça sobre a construção do mito do progresso ou da construção da imagem do bandeirantismo paulista. Em síntese, esse evento central serviu para diferentes setores sociais ativarem ou criarem uma memória coletiva positiva capaz de justificar uma espécie de destino manifesto, numa trajetória linear e ininterrupta da vila São Paulo de Piratininga à metrópole que mais crescia no país e considerada locomotiva econômica da nação.

\footnotetext{
* Este artigo é um fragmento da tese de doutoramento do autor (Silva, 2011). Parte dele foi apresentado no seminário temático Linhagens do Pensamento Político-Social Brasileiro, em novembro de 2009, e no curso de formação promovido pelo grupo Edições Toró, em maio de 2010. Aos interlocutores dessas ocasiões em que o texto foi discutido, agradeço especialmente aos professores Elide Rugai Bastos, André Botelho, Glaucia Villas-Bôas, Petrônio Domingues e Priscila Nucci, bem como a Marcelo D'Salete, Allan da Rosa e aos ouvintes do curso Resistência e Anunciação: Arte e Política Preta.
} 
Acionados jesuítas, bandeirantes e, quando conveniente, frações imigrantes europeias, a construção da epopeia bandeirante situava a cidade - irradiando-se ao estado como um ponto de inflexão, no momento das comemorações, de um ideal de modernidade, superação e distanciamento do atraso que grassava a história brasileira. Identificava-se a um só tempo um sujeito social (personagens históricos que forjassem a imagem positiva dos paulistas) selecionava-se um tema (a épica do destemor e da bravura bandeirante) e conferia-se um sentido (do progresso ilimitado, concretizado simbolicamente na escultura espiral ascendente do IV Centenário, projetada por Oscar Niemeyer para o Parque do Ibirapuera, que não chegou a ser construída).

Esses elementos formam um imaginário social, servindo aos interesses de quem os organizou: parcelas da intelectualidade, do empresariado, grupos financeiros, políticos, 228 paulistas "tradicionais" de quatrocentos anos e profissionais liberais de classes médias (os últimos ligados ao setor de serviços interessados em lucrar ou ser subvencionados com os aportes das comissões organizadoras, criadas pelo poder público e responsáveis pelas comemorações) (Lofego, 2004, p. 11).

Entretanto, entre os grupos humanos que constituíram esse estado e cidade, deliberadamente se ocultaram, em meio aos processos comemorativos, negros e indígenas $^{1}$. Identificados ao atraso, tiveram sua participação na construção de São Paulo questionada. No caso dos negros, isso não impediu que frações organizadas desse grupo - e

\footnotetext{
1 "Em meio ao bombardeio ufanista, é difícil encontrar imagens ou vozes destoantes, mas elas existem, quase sufocadas, emergindo em alguns protestos, ora de artistas que eram excluídos do reconhecimento oficial, ora de grupos atuantes, como a comunidade negra de São Paulo, a qual também buscava maior reconhecimento de sua importância para a memória paulista" (Lofego, 2004, p.33).
} 
que já vinham de experiências políticas anteriores, interrompidas pelo golpe do Estado Novo, rearticuladas após $1945^{2}$ - procurassem reordenar projetos coletivos, colocando em xeque a posição subalterna que lhes fora relegada no pós-Abolição.

Simultaneamente, procuraram construir um ponto de referência que, no mesmo compasso, reavaliasse o passado e o positivasse, através de eventos e figuras históricas importantes para o grupo, tentando configurar assim uma identidade alternativa - focada na promoção da ideia de cultura - à servidão forçada, como forma de valorização do sujeito negro, lidando, desse modo, com os desafios da cidadania no presente de meados do século XX.

Pretende-se discutir aqui, em linhas breves e de forma não conclusiva, a atuação da Associação Cultural do Negro (ACN), organização que surge em 1954 e cessa atividades em 1976, cuja gênese é decorrente da reação de parte daquele grupo social às comemorações do quartocentenário paulistano; e cujos objetivos vão se ampliando em outras direções no período mais profícuo de sua existência, de sua fundação até o golpe de 1964. Importante dizer que se trata de uma organização negra pouco estudada pela bibliografia sobre relações raciais no Brasil, apesar de sua importân-

\footnotetext{
2 "O Clube Negro de Cultura Social continuou trabalhando para fazer as comemorações do Cinquentenário da Abolição, que seria no 13 de maio de 1938. Por causa disso, o Cultura não foi atingido pela Lei de 10 de novembro de 1937. [...] O Estado Novo - nome que o Getúlio deu à ditadura - terminou com todos os movimentos de lutas sociais do negro porque eram lutas de classe. Aí o Movimento Negro parou e o Cultura, terminados os festejos do Cinquentenário da Abolição, foi intimado a fechar. [...] até quando terminou a guerra com a vitória dos aliados. Por essa época, havia na avenida São João um escritório do Raul [Joviano] do Amaral com um tal de Mário da Silva Júnior, onde começaram a aparecer algumas pessoas da antiga Frente Negra Brasileira, como o Francisco Lucrécio, Roque dos Santos e outros. Então nós fomos convidados, eu e o [Fernando] Góis e outros, que éramos do grupo d'O Clarim d'Alvorada, para ver se conseguíamos fazer uma recuperação do trabalho perdido desde 38. [...] conseguimos os meios para iniciar a Associação dos Negros Brasileiros” (Leite e Cuti, 1992, pp. 131, 137, 142).
} 
cia, sendo citada em parágrafos de poucos artigos e textos sobre o tema ${ }^{3}$.

Como foi discutido em Silva (2010, 2011), os caminhos da ACN e seus membros se cruzam também com os da sociologia uspiana, notadamente através de Roger Bastide e Florestan Fernandes, visto que esses cientistas sociais se valeram do contato com os ativistas negros, circulando em seus espaços e estabelecendo relações, que foram importantes para seus principais trabalhos sobre a questão racial: Brancos e negros em São Paulo e A integração do negro na sociedade de classes.

\section{Uma associação cultural do negro em meados do século XX}

Em atividades associativas e organizadas política e culturalmente, frações do grupo negro paulistano se encontravam, no pós-abolição, desde o começo do século XX. Os jornais 230 da imprensa negra e grupos reivindicativos como a Fren-

3 A ACN é citada por Florestan Fernandes (1978), Clóvis Moura (1983), Miriam Ferrara (1986), sendo que esses autores discutem rapidamente aspectos da organização e/ou utilizam os depoimentos de seus membros e jornais como fontes. Mereceu ainda uma apresentação em congresso, por Petrônio Domingues (2007) e um capítulo de tese, além de diferentes menções, em Silva (2011). Algumas vezes é referida equivocadamente, como em Regina Pahim Pinto (1993), que afirma a associação ter sido fundada "pelo poeta Solano Trindade, pelo escritor Abdias do Nascimento, além de um grupo de intelectuais e jornalistas" (1993, p. 354). Trindade pertencia ao Teatro Popular Brasileiro, de cunho folclórico. E Nascimento, no Rio de Janeiro, fundou e liderou o Teatro Experimental do Negro, ambos sem relações formais com a ACN. Ou, ainda em Silva (1994), para quem o objeto de sua dissertação, o Centro de Cultura e Arte Negra "foi a primeira organização negra, na capital de São Paulo, a atuar, trazendo, entre outras propostas, as ideias de Negritude, ou seja, a importância da consciência étnica, colocando a necessidade de redescoberta do negro, a partir da recuperação do domínio cultural e histórico [...] O que diferencia o Cecan dessas duas entidades negras, Associação Cultural do Negro e Frente Negra Brasileira, é o fato de sua liderança apresentar um discurso e atuação na tentativa de construir uma consciência negra e uma identidade étnica [...] algo que não aparecia até então" (1994, pp. 11, 22). Ao longo deste artigo, ver-se-á em que consistem tais imprecisões. O que sobrou do acervo da ACN encontra-se conservado na Unidade Especial de Informação e Memória da Universidade Federal de São Carlos (Ueim-UFSCar), arquivo que guarda a documentação primária consultada e citada no decorrer do texto. 
te Negra Brasileira (1931-1937), o Clarim d'Alvorada, entre muitos outros, desenvolviam atividades e ações efervescentes que seriam interrompidas, em 1937, reestruturando-se somente no fim dos anos 1940 (Bastide e Fernandes, 1955; Fernandes, 1978; Bastide, 1973; Moura, 1983; Ferrara, 1986; Leite e Cuti, 1992; Barbosa, 1998; Domingues, 2008).

Entre 1948 e 1953, em São Paulo e Rio de Janeiro, as atenções do grupo negro organizado estão voltadas ao Primeiro Congresso do Negro Brasileiro (transcrito quase integralmente em Nascimento, [1968] 1982), realizado em 1950 no Rio de Janeiro ${ }^{4}$, e à pesquisa Unesco (Maio, 1997), da qual participam como sujeitos pesquisados ${ }^{5}$, dentre outras ações menores, em função de suas atividades pregressas. O cotidiano da cidade paulistana se impõe aos sujeitos sociais de maneira impactante, dadas as transformações pelas quais a metrópole vinha passando, notando-se alterações arquitetônicas, intervenções no espaço público, mudanças na dinâmica das relações pessoais interferindo na vivência dos moradores das "várias 'cidades' que coexistiam lado a lado" (Fernandes, 1977, p. 144), que vinham se preparando, no mesmo período, para as comemorações do IV Centenário de São Paulo.

\footnotetext{
4 Esse congresso foi "organizado pelo grupo do Teatro Experimental do Negro, tendo à frente o Abdias do Nascimento. [...] estiveram presentes vários sociólogos de renome. Uma das teses que deu margem a muitos comentários foi a do Ironides Rodrigues, com o título 'Estética da Negritude' [...] Foi daí que se começou falar muito de Negritude no meio negro. A finalidade desse Congresso era de reunir subsídios para uma pesquisa idêntica à que houve aqui em São Paulo, patrocinada pela Unesco" (Leite e Cuti, 1992, p. 162).

5 "Há um esforço pioneiro para entender o papel dos movimentos sociais e de seus líderes no esforço de revisão da posição dos negros na sociedade. Para compreender esses processos foi essencial a decisão inovadora de chamar os líderes daqueles movimentos para participarem das discussões e mesmo para orientarem muito das interpretações acolhidas na pesquisa. Houve um ensaio de sociologia participativa. Essa técnica, bem como a combinação dela com outras, desde a reconstrução histórica da vida social dos negros e das formas do preconceito até a utilização de técnicas de pesquisa de campo, mostram a ousadia metodológica do empreendimento de Bastide e Florestan” (Cardoso, 2008, pp. 15-16).
} 
Essas se propunham a ser, simultaneamente, grandiosas e excludentes, tendo São Paulo como "uma espécie de resumo do Brasil ou seu ponto de convergência" (Lofego, 2004, p. 39), em que "o elã comemoracionista de São Paulo no IV Centenário é, a médio prazo, uma resposta à derrota política e à vitória econômica. Perdeu-se a batalha de 1932, mas não a guerra da industrialização e do desenvolvimento" (Arruda, 2001, p. 98).

Recorde-se que, entre alguns setores intelectuais paulistanos, o grupo negro e suas frações organizadas eram vistos com desconfiança, acusados de colaborar ou simpatizar com as ações e propostas getulistas, na ocasião do confronto de 1932, transformando-se, portanto, em inimigos dos paulistas, como sugerem os artigos escritos por Paulo Duarte, em 1947, para o jornal O Estado de $S$. Paulo, utilizando esse tópico para questionar a identidade nacional brasileira ${ }^{6}$. A visão de Duarte, no entanto, esta232 va equivocada por, ao menos, três fatores: 1) o desmantelamento progressivo das organizações negras a partir de 1932, culminando em sua proibição em 1937; 2) a criação do destacamento militar denominado Legião Negra, em 1932, para lutar com os paulistas contra o governo Vargas; 3) o fim da principal organização negra do período, a Frente Negra Brasileira, depois de sucessivos ataques, por conta do golpe do Estado Novo (Leite e Cuti, 1992; Barbosa, 1998; Domingues, 2008).

\footnotetext{
6 "Começa a surgir no Brasil, com todo horror que o caso encerra, um problema que, por não existir, era o capítulo mais humano talvez da nossa história social: o problema do negro. O curioso porém é que aparece agora não criado ou agravado pelo branco, mas por uma prevenção agressiva que se estabelece da parte do negro contra o branco. É mais um legítimo fruto podre entre tantos com que nos aquinhoou a ditadura" (Duarte, 1947a, p. 5). O problema era provocado por esse negro de novo tipo, associado e reivindicativo, muito distante da imagem do negro dos tempos dos avós (Duarte, 1947b, p. 6). O artigo de O Estado de S. Paulo recebeu resposta de José Correia Leite, no jornal Alvorada, intitulado "O Esgar do Sr. Paulo Duarte" (apud Leite e Cuti, 1992, pp. 258-259). Ainda sobre "Negros do Brasil”, ver Bastos (1988, pp. 20-27) e Silva (2011, pp.123-132).
} 
Depreende-se também, em meio aos jogos de poder, a exclusão simbólica da participação do negro no processo social que culminara até ali; inclusive burocraticamente, pelas duas comissões organizadoras do evento em 1954 que recebeu:

entre as sugestões e propostas enviadas ao diretor do serviço de comemorações culturais, Roberto de Paiva Meira, havia a proposta da Comissão de Festejos para Ereção de um Monumento à Mãe Negra que, como o próprio nome diz, pretendia inaugurar um busto no Largo do Paissandu, em homenagem à mãe preta, inserindo-se no espaço da capital paulista como símbolo da cultura negra em São Paulo. [...] A proposta rejeitada por diversas ocasiões, somente foi aceita quando [essa] Comissão [...] entregou à $[. .$.$] do IV Centenário um abaixo-assinado.$ Diante de tal apelo, além de tal homenagem integrar as comemorações do Quartocentenário, diversas autoridades estiveram presentes na inauguração, inclusive o governador do estado [...]. Entretanto é contrastante observar que a proposta encaminhada pelo Grupo de Industriais e Artistas, representados por Teodoro Procópio, para construção de um grandioso Museu de Cera na marquise do Ibirapuera foi aceita sem maiores restrições (Lofego, 2004, pp. 50-52).

Na dinâmica da comemoração, inventa-se uma tradição para o progresso e o "destino manifesto" de São Paulo; funda-se uma genealogia de bravura e uma história épica. Tenta-se forjar a imagem de uma metrópole moderna, mesmo que ela padeça de dilemas periféricos, como as favelas:

O território escolhido para ser símbolo das festas [o futuro Parque do Ibirapuera] estava ocupado por populações que, no entender dos poderes que estavam à frente daquele projeto, não integravam a grandeza de São Paulo, por 
isso era preciso removê-las e deixar o território ficar livre para a edificação dos marcos da "pauliceia" triunfante [...] consta que ao final das operações solicitadas e executadas pelo poder público, foram removidos 186 barracos, que abrigavam 204 famílias. [...] [Na documentação sobre a remoção] não encontramos qualquer menção à sorte dessa população (Lofego, 2004, pp. 83-84) ${ }^{7}$.

Vivendo os reflexos de golpes incompletos de modernização - notadamente a Abolição e a República - que lhes favoreceram lateral e insuficientemente e contra os quais reivindicam continuamente, em associações, jornais e órgãos políticos; compondo parcelas significativas da população pobre ou desprivilegiada da cidade, é significativo, portanto, que frações do grupo negro paulistano tivessem de quê reclamar e tentar arregimentar membros para suas reivindicações, através de seus jornais, clubes e 234 organizações.

Ao criar, em 1954, a ACN, os antigos militantes do meio negro organizado em São Paulo afirmam que era necessário, novamente, tentar aglutinar interessados para a questão do negro, irresoluta; e, dado o apagamento no Quartocentenário, tornada uma questão menor. Um de seus principais líderes foi o militante José Correia Leite ${ }^{8}$. Ele e outros membros da nova associação, como Jayme de Aguiar, Raul Jovia-

\footnotetext{
7 O mesmo episódio é citado por Arruda (2001, pp. 89-90). Sobre as favelas em São Paulo e seu surgimento, Jorge Paulino (2007) discute o assunto, demonstrando quão vacilantes são os arranjos de modernização da cidade, uma vez que as primeiras favelas, substituindo os cortiços, na década de 1940, são estimuladas e fomentadas pela prefeitura municipal, sendo que esta fornece, inclusive, terrenos públicos e materiais para construção de moradias precárias.

8 Correia Leite (São Paulo, 1900-1989) foi um dos principais ativistas e intelectual da imprensa e associações negras em São Paulo. Ajudou a fundar o Clarim d'Alvorada em 1924, a Frente Negra Brasileira em 1931, Clube Negro de Cultura Social em 1932, Associação dos Negros Brasileiros em 1947, Associação Cultural do Negro em 1954, além de outras iniciativas. Serviu de depoente, junto com outros ativistas e intelectuais negros, aos trabalhos de Florestan Fernandes (1978), Clóvis Moura (1983), Miriam Ferrara (1986). Ver Leite e Cuti (1992).
} 
no do Amaral, Henrique Cunha, participaram ativamente, como informantes e sujeitos pesquisados, da pesquisa Unesco em São Paulo. Mantinham relações próximas com Roger Bastide e Florestan Fernandes, sendo que estes participavam das manifestações e associações daqueles. Forneceram-lhes dados, entrevistas, documentos, jornais etc. Há um encontro fecundo, nesse sentido, entre ativistas negros e sociólogos, especialmente em São Paulo ${ }^{9}$.

Se o começo dos anos 1950, havia se imposto aos cientistas sociais com o dilema sintetizado, de maneira precisa, em Villas-Bôas $(2006)^{10}$, tomando a questão racial, entre

9 Sobre esse encontro, afirmou Raul Joviano do Amaral que, entre os anos 1940 e 1950, depois de conhecer Bastide - por iniciativa deste - no casarão onde funcionava a associação José do Patrocínio: "Comecei, então, a ter contatos mais frequentes com o Mestre, ora na Faculdade, ora em meu escritório, ora em minha casa, que ele honrava [...] Mais intensa e mais íntima se tornou a convivência com Bastide quando Mário Wagner Vieira da Cunha - meu colega na Comissão do Serviço Civil do Estado - anunciara-me a próxima realização dos estudos regionais sobre o negro, sob os auspícios da Unesco, pesquisas coordenadas por Bastide com o inconfundível concurso de Florestan Fernandes e assessoramento preciso de Lucila Hermann" (Amaral, 1978, pp.126-127). Correia Leite afirma ainda que: "Apareceu aqui [...] Jorge Prado Teixeira. Era um rapaz que quase ninguém conhecia. Ele apareceu como intermediário dos pesquisadores com o meio negro. Ele estava autorizado e começou a fazer os convites [dos seminários] e a participar de reuniões com os membros da pesquisa" (Leite e Cuti, 1992, p. 152); "a [pesquisa] mais bem feita foi a de São Paulo, pois na metodologia os professores utilizaram os alunos para saírem pelas ruas, irem à porta de fábrica etc. Eu fui procurado, também, por um rapaz que depois se tornou muito meu amigo. Ele se formou em sociologia e foi aluno do Prof. Roger Bastide. O nome dele era Renato Jardim Moreira. Ele fez comigo um trabalho sobre a minha participação nas lutas sociais, nas entidades e nos jornais [...] Em 1950 eu completei 50 anos. O Fernando Góis resolveu me oferecer um jantar e deu o nome de Cinquentenário de José Correia Leite. [...] Houve almoços e jantares interessantes. Como o Renato Jardim Moreira estava integrado nas nossas reuniões, convidou os professores Roger Bastide e Florestan Fernandes para um jantar, devido o Prof. Bastide ter chegado de Paris em suas primeiras férias [...] O Prof. Roger Bastide, em sua conhecida humildade, não queria aceitar ser ele o homenageado no momento, já que se tratava do meu aniversário. A festa terminou auspiciosamente" (Leite e Cuti, 1992, pp. 153, 159-160).

10 "A sociologia brasileira dos anos 1950 apresenta uma longa reflexão sobre a compreensão que os sociólogos tinham de si mesmos e sobre as tarefas que julgavam relevantes para a sua disciplina. O projeto que eles esboçaram para o seu campo intelectual é de importância para o entendimento da noção de tempo, que fundamenta não apenas os ideais de mudança que almejavam para o país, como também a sua função intelectual inscrita no trabalho de pesquisa e análise dos 
outras, como laboratório de testes para se pensar o problema da mudança social no Brasil, para o grupo negro, cabe pensar que o dilema proposto, explicitado pela autora, permite criar, em paralelo, a seguinte ideia síntese: fazer história, fazer sentido. A proximidade e distanciamento simultâneos dos eventos abolicionistas (e de suas decorrências imediatas), bem como as ações que lograram realizar nas décadas seguintes (criar jornais, associações, organizações, editar livros etc.), colocam questões cruciais ao grupo e ao tempo histórico que vivem, nos quais investem em ações e propostas visando interferir e alterar positivamente a história do negro. Essas ações são analisadas em detalhe por Bastide e Fernandes (1955, 1964), bem como por Virgínia Leone Bicudo, em 1945, com seus estudos sobre as atitudes raciais de pretos e mulatos, entrevistando pioneiramente membros da Frente Negra Brasileira (Bicudo, 2010).

236 Esses investimentos num certo sentido da história social e cultural remetem a José Correia Leite que, em suas memórias, ao lembrar o surgimento da ACN, afirma o seguinte:

Em 1954, nas comemorações do Quartocentenário [...] houve muitas festas, mas o negro não se fez presente, isto porque naquele ano não havia uma entidade organizada para tratar do assunto [...] Quem construiu propriamente a cidade foi o negro [...] Com tudo isso, houve alguns negros interessados em fazer qualquer coisa [...] mas foram pedir auxílio pro governo e receberam uma recusa. Isso eu soube [...] Mas eu achei que esse negócio não estava certo e então nós tínhamos de fazer uma outra entidade mesmo. Por casualidade encontrei-

fatos sociais. Seu grande desafio era estabelecer uma correspondência entre fazer ciência e fazer história [...] Os sociólogos se autorrepresentam enquanto agentes que através do conhecimento contribuem para a realização da história" (Villas-Bôas, 2006, pp. 65, 79; grifos da autora). 
me com o Borba [José de Assis Barbosa], que já tinha dado uma iniciativa sobre a ideia da fundação de uma entidade cultural [...] Achei que uma entidade cultural, de propaganda em defesa dos valores negros, isso era o suficiente para a presença do negro no movimento cultural e cívico da cidade (Leite e Cuti, 1992, p. 163).

Fundada formalmente em 28 de dezembro de 1954, a $\mathrm{ACN}^{11}$ situa-se inicialmente no centro da capital paulista, no terceiro andar de um edifício na praça Carlos Gomes, número 153. Em que pese a quantidade de entidades associativas de negros no estado de São Paulo, em meados do século XX, verificável em documento do acervo da $\mathrm{ACN}^{12}$, colocando em questão o ineditismo dessa associação, cabe destacar sua singularidade.

Sua localização espacial não é de importância menor: o centro da cidade é um lugar de passagem considerável, permitindo o encontro com sujeitos diversos da vida cultural e política, bem como a concentração de associados ou

${ }^{11}$ Em função do momento político e das dificuldades de reorganização da militância negra, segundo Correia Leite, havia, inclusive, desconfiança em relação ao nome da nova associação: "Muitos achavam que era uma continuação do Clube Negro de Cultura Social, mas não era nada disso. [...] era um nome muito perigoso, ia causar mal-estar no meio branco, alguma espécie até de provocação [...] Aqui em São Paulo tinha um clube de dança chamado Clube 220. Não tinha quase expressão. Mas com o surgimento da Associação Cultural do Negro, ele aproveitou a ocasião para também tomar uma posição [...] começaram a criar intriga. A sigla da Associação Cultural do Negro era ACN. Então, eles começaram a dizer que éramos a Associação Comunista dos Negros. Mas não estávamos ligando para isso" (Leite e Cuti, 1992, pp. 164-165).

12 Algumas das associações negras listadas na correspondência são: Clube Ébano (Santos), Grêmio Recreativo Familiar Flor de Maio (São Carlos), Sociedade Dansante [sic] Familiar José do Patrocínio (Rio Claro), Sociedade Luiz Gama (Jaú), Clube Recreativo Luiz Gama (São João da Boa Vista), Sociedade Cultural Luiz Gama (Bauru), Society Colored Pinhalense (Pinhal), Sociedade Beneficente 13 de Maio (Piracicaba), Clube Recreativo 13 de Maio (Itapetininga), Clube Recreativo 13 de Maio (Limeira), Sociedade Beneficente Cultural e Recreativa 28 de Setembro (Sorocaba), Sociedade Beneficente e Recreativa Jundialense 28 de Setembro (Jundiaí), entre outras. Ver a Coleção Associação Cultural do Negro, Acervo Ueim-UFSCar. 
simpatizantes da ACN. O ponto inicial era bom, mas não o suficiente para atender as especificidades de suas atividades e frequentadores: era necessário que funcionasse à noite, para que seus membros pudessem, após o dia de trabalho e estudo, participar das atividades.

Nesse sentido, a organização muda-se, antes de julho de 1956, para a rua São Bento, no edifício Martinelli. Embora haja agora uma elasticidade no tempo das atividades noturnas, existe também algum receio inicial no aceite da mudança. A ACN era uma entidade com diferentes propósitos, dentre os quais os de não partidarizar a causa do negro (medo da desmobilização exterior, provocada pelo Estado Novo) e, também, criar uma aura de respeito à imagem pública do grupo que procurava representar. O Martinelli, apesar da importância histórica, localização privilegiada e horário propício, colocava em xeque, aparentemente, as duas coisas.

Quando ele [José de Assis Barbosa] conseguiu aquele espaço no prédio Martinelli, a gente ficou naquela dúvida de mudar ou não. Porque o prédio Martinelli era um lugar de má fama, um prédio em que famílias não gostavam de ir. Lá dentro havia marginais, viciados... Nós resolvemos, não havia outra saída. São Paulo só tinha aquele prédio que funcionava a noite inteira. Lá nós não tínhamos hora de fechar. O conjunto era no $16^{\circ}$ andar. No 17을 havia a sede do Clube 220, dos que chamavam a Associação Cultural do Negro de Associação Comunista dos Negros [...] Havia comunistas no nosso meio, mas não era permitido que se fizesse política dentro da entidade (Leite e Cuti, 1992, pp. 169-170).

Vencidas as desconfianças iniciais em relação à nova sede e ao nome, a ACN dá prosseguimento às suas atividades, havendo um intervalo de ano e meio para sua primei- 
ra grande atuação pública ${ }^{13}$. No ano de 1956, realiza uma Quinzena 13 de Maio, junto com o Teatro Experimental do Negro de São Paulo (TEN-SP, dirigido por Geraldo Campos de Oliveira, também membro da ACN). A Quinzena se aliou à preparação da Primeira Convenção Paulista do Negro, que era executada desde abril daquele ano. Entre os diferentes teores de moções apresentadas à Convenção Paulista, distinguiu-se a de Henrique Losinskas Alves, intelectual filho de migrantes lituanos e colaborador da ACN (Angelo e Reipert, 1989; Leite e Cuti, 1992), propondo a realização de uma Semana Nina Rodrigues, em comemoração ao antropólogo e médico nordestino, pioneiro do estudo negro e/ou africanista no Brasil.

Não foi bem aceita inicialmente ${ }^{14}$. Entretanto, a Semana ocorreu de 17 a 24 de julho de 1956, segundo a contracapa de Alves (1963). No primeiro dia, Losinkas Alves pronunciou a conferência "A realidade de Nina Rodrigues", no auditório da Biblioteca Mário de Andrade. No terceiro

13 “A Associação Cultural do Negro iniciou suas atividades em 1955, depois da aprovação do Estatuto Social. No primeiro artigo desse documento, ficava estabelecido que a ACN era uma sociedade civil, com a 'finalidade de propugnar pela recuperação social do elemento afro-brasileiro'. No terceiro artigo, ficava estipulado que a entidade visava: 'a) coordenar, esclarecer e orientar em todas as atividades de caráter econômico, educacional, cultural, político e social, o elemento negro preferencialmente; b) estimular e desenvolver o pensamento cooperativista, procurando instituir cooperativas econômicas e culturais, principalmente cooperativas de ensino; c) promover, na medida de suas possibilidades financeiras, a prestação de serviços de assistência social e jurídica; d) estimular a arregimentação à base de famílias, para um maior congregamento, no sentido do permanente espírito de solidariedade e fraternidade; e) dedicar especial atenção e amparo à mulher e à infância de maneira a consolidar as bases da educação como fator fundamental da recuperação social do elemento afro-brasileiro"” (Domingues, 2007, p. 3).

14 "Mas foi ele o primeiro - o único mérito que ele teve. Porque as opiniões que ele defendia com relação ao negro mais tarde foram contestadas como negativas [...] Terminada a convenção, parecia que a ideia morria ali mesmo. Acontece que o Henrique L. Alves começou a persistir para a realização do projeto. [...] Estabelecemos qual era o programa da Semana Nina Rodrigues, que começou com uma exposição de objetos folclóricos, principalmente da cultura religiosa negra [...] $\mathrm{O}$ Ironides Rodrigues quem fez o encerramento da semana, na sede da Associação. A imprensa deu uma grande cobertura, por se tratar de um nome por muito tempo esquecido" (Leite e Cuti, 1992, p. 166). 
dia, na antiga sede da ACN, o antropólogo baiano Édison Carneiro fez nova conferência sobre Nina Rodrigues. No penúltimo dia, Ironides Rodrigues, intelectual negro do TEN, realizou outra conferência no auditório da Biblioteca Municipal.

É interessante notar, embora não se saiba exatamente o que foi enunciado (com exceção o texto de Alves, publicado posteriormente pela ACN), a importância simbólica dos lugares das conferências e de seus palestrantes. De acordo com a documentação coligida no acervo da ACN, os diretores da associação tinham plena consciência disso. A preparação da Primeira Convenção Paulista do Negro era executada desde abril de 1956, tendo sido elaborado regimento com vinte artigos dispondo sobre a organização do evento. A diretoria da ACN enviou cartas-convite para, dentre outros, o então governador do estado, José Porphyrio da Paz que, em telegrama a Geraldo Campos de Oliveira, agra240 dece pelo convite, mas afirma que não pode comparecer ${ }^{15}$.

Há aí uma estratégia de visibilidade e reconhecimento, que se repetiria ao longo da curta existência da associação. É possível encontrar, em outras ocasiões, respostas dos governadores Jânio Quadros, José Porphyrio ou Carlos Alberto Carvalho Pinto a solenidades e comemorações promovidas pela $\mathrm{ACN}^{16}$. Todos eles agradecem e não aceitam os convites feitos. Então, cabe perguntar: visibilidade e reconhecimento almejados para qual público? Além da diretoria, composta de sujeitos ungidos em experiências políticas e culturais anteriores, e da trupe do TEN-SP, com seus atores e escritores, quem mais frequentava a ACN? De acordo com Oswaldo de Camargo ${ }^{17}$, à ocasião em que convivia e

15 Telegrama de José Porphyrio da Paz a Geraldo Campos de Oliveira, Coleção Associação Cultural do Negro, Acervo Ueim-UFSCar.

${ }_{16}$ Telegramas na Coleção Associação Cultural do Negro, Acervo Ueim-UFSCar.

17 Oswaldo de Camargo nasceu em Bragança Paulista, em 1936. É jornalista, atuando simultaneamente na imprensa negra e nos jornais do grupo O Estado de 
participava da associação, já no edifício Martinelli (entre julho de 1956 e meados dos anos 1960, portanto):

Negros que têm uma casa boa mesmo, são dois, três. Contam-se nos dedos. Não há um negro em política militando. Militando não: não há um negro em cargo político, de verdade. A história recente do negro é uma história de domésticas. Aquelas meninas lindas estão ali, quase todas são domésticas. Trabalham em casa de família, raras professoras. De vez em quando uma professorinha, muito difícil [...] Uma boa parte de negros trabalham em empregos [de] funcionário público [...] Você tem que levar em conta que a Associação ela tem um impasse tremendo. A intelectualidade, o grupo de intelectuais, era um grupo minoritário. O grupo mais forte da Associação era o grupo que me levou à Associação, que é o grupo do convescote, do piquenique, do esporte, que era mais forte que a Literatura [...] A Associação tinha crise de aluguel, os sócios não pagavam a tempo. Era assim. Era uma associação pobre, eram dois cômodos, no décimo sexto andar $^{18}$.

Todavia, embora o grupo literário/intelectual fosse minoritário e apesar das limitações monetárias dos associados, a ACN se organiza para o ano de 1958, quando se comemora o $70^{\circ}$. aniversário da Abolição da Escravatura. E será nessa ocasião que muitos eventos relevantes para a discussão empreendida aqui se realizarão.

\footnotetext{
S. Paulo. Em 1959, publicou seu primeiro livro de poemas, Um homem tenta ser anjo (com apresentação de Sergio Milliet). Em 1961, já pela ACN, publicou os 15 poemas negros, apresentados por Florestan Fernandes. Atuou nos jornais Níger, Mutirão e Novo Horizonte, todos vinculados à ACN. Entre 1972 e 1987, publicou $O$ carro do êxito, A descoberta do frio, O estranho, A razão da chama (esses últimos são antologias de literatura negra). Atualmente é consultor do Museu Afro-Brasil, de São Paulo.

${ }^{18}$ Entrevista de Oswaldo de Camargo concedida ao autor em 29/07/2007, São Paulo.
} 


\section{Ano 70 da Abolição}

Apesar das dificuldades internas, entre fins de 1956 e início de 1958, a diretoria da ACN se organiza para e faz saber das comemorações em torno do que ficou simbolicamente batizado como o Ano 70 da Abolição. Se o quinquagésimo aniversário da data não pôde ser comemorado e utilizado publicamente, em razão da ditadura varguista; e o sexagésimo não suscitou tantas agitações conhecidas, sendo sublimado por outras atividades, é curioso observar o porquê 1958 se tornar uma data tão importante para frações do grupo negro. Ao que parece, do que é possível deduzir das fontes, não há força maior que o próprio contexto. Uma brecha democrática, um conjunto de associações disponíveis, grupos e sujeitos interessados, alguma receptividade interna e externa àqueles grupos em relação ao assunto. E, em particular à ACN, tinha-se em mãos a possibilidade de estratégia de visibilidade maior aos seus feitos.

242 Ocorre a criação de um movimento cívico-cultural comemorativo do aniversário da abolição do trabalho escravo no Brasil $^{19}$, com um conjunto de entidades e sujeitos organizados, nem todos diretamente tocados pela questão negra. Os procedimentos adotados vão desde dar ciência à sociedade, de maneira ampla, de que se pretendia e o quê iria ocorrer, até os pedidos de doação financeira (a bancos, entidades etc.) para o evento efetivamente acontecer ${ }^{20}$. A organização

\footnotetext{
19 De acordo com carta do escritor Eduardo de Oliveira a Geraldo Campos de Oliveira, de 13/05/1958. Documento da Coleção Associação Cultural do Negro, Acervo Ueim-UFSCar. Correia Leite afirmará que "A primeira proposta de grande impulso na Associação Cultural do Negro foi a de se comemorar o Ano 70 da Abolição. Mas, para não se dizer que queríamos açambarcar as comemorações, formamos uma comissão e foi lançado um pequeno manifesto. Ficou estabelecido que a festa seria o ano inteiro com conferências e festivais lítero-musicais na sede, festivais esportivos..." (Leite e Cuti, 1992, p. 171).

${ }^{20}$ Nesse sentido que, por exemplo, a comissão organizadora envia ofício à secretaria de educação do governo do estado de São Paulo, em 24/02/1958, informando as intenções e, porventura, solicitando apoio; recebe votos de auxílio da Câmara Municipal de São Paulo; homenagem da Sociedade MMDC Veteranos de 1932,
} 
atinge o ponto alto almejado distribuindo o manifesto lançado em São Paulo, em janeiro de 1958. O documento, reproduzido em Camargo (1972, p. 95), afirmava que:

Neste ano de 1958 em que comemoramos o 70 aniversário da abolição da escravatura no Brasil, as organizações culturais, esportivas, recreativas e as pessoas que a este subscrevem, uniram-se para homenagear os grandes vultos que, no passado, batalharam nas tribunas, na imprensa, nos parlamentos, nos eitos, nas senzalas e nos quilombos por causa tão justa e humana. [...] Tais vultos merecem a homenagem e o respeito de todo o povo brasileiro, e, os ideais de liberdade e independência que nortearam suas grandes ações, elevam e enobrecem os sentimentos de humanidade de nossa gente. [...] No momento em que se exaltam no Brasil os sentimentos de nacionalidade, independência e liberdade, adquire ainda maior oportunidade a comemoração do grande feito de 1888 [...] Através de sessões cívicas, conferências culturais, representações de teatro, festejos populares, atividades esportivas e recreativas, desejamos que todos os brasileiros participem das festividades comemorativas do "O Ano 70 da Abolição”, contribuindo dessa maneira para elevar ainda mais alto a chama democrática da igualdade jurídica e social das raças.

Salve o Ano 70 da Abolição

São Paulo, janeiro de $1958^{21}$

pela participação do negro na Revolução Constitucionalista; ou donativo do Banespa; além de uma carta do então vice-governador de São Paulo, General José Porphyrio da Paz. Conforme documentação do Acervo ACN da Coleção Associação Cultural do Negro, Acervo Ueim-UFSCar.

${ }^{21}$ Assinam o documento: Geraldo Campos de Oliveira (Presidente da ACN), Solano Trindade (Diretor do Teatro Popular Brasileiro), Dalmo Ferreira (Diretor do Teatro Experimental do Negro de São Paulo), Dr. Milton Freire de Carvalho (Diretor da Associação Paulista dos Homens do Norte e do Nordeste), César Fernandes Leite (Presidente do Fidalgo Club), José Maria Bernardelli (Diretor do Grêmio Estudantil Castro Alves) e José Maria César (Presidente da Sociedade Recreativa José do Patrocínio, de São Manuel). 
Trata-se de uma carta de tom conciliador e agregador. Informa e convida, menos que denuncia e propõe. Mas tal modulação discursiva foi eficaz em congregar elementos tão díspares a um fato, considerado por aqueles ativistas negros, de importância maior. Para José Correia Leite, numa síntese, o saldo parece ser positivo de toda a articulação em torno do "Ano 70", pois

Dentro daquele ano dos festejos do Ano 70 da Abolição, a Associação conseguiu do governador do Estado, o Jânio Quadros, uma colaboração. Ele não deu dinheiro, mas pôs a gráfica do Estado à disposição da nossa entidade para que fossem confeccionados os impressos para divulgação. Nós tínhamos entrado em contato com vários intelectuais para fazerem conferências, como o Sérgio Milliet, Artur Neves e outros. Numa dessas conferências, feita na Biblioteca Municipal, quem falou foi o Prof. Carlos Burlamáqui Köpke. Ele discursou sobre André Rebouças, um negro pouco falado, pouco conhecido [...] Quantos às publicações, depois que terminaram as comemorações do Ano 70 da Abolição, foi publicado o primeiro Caderno da série Cultura Negra, contendo uma espécie de anais dos trabalhos apresentados em 1958 (Leite e Cuti, 1992, p. 171, 173-174).

\section{É também nesse ano que se declama o poema "Protesto"22}

\footnotetext{
22 Alguns excertos: "Mesmo que voltem as costas/ às minhas palavras de fogo/ Não pararei/ Não pararei de gritar/ [...]/Senhores/ Atrás do muro da noite/ Sem que ninguém o perceba/ Muitos de meus ancestrais/ Já mortos há muito tempo/ Reúnem-se em minha casa/ E nos pomos a conversar/ Sobre coisas amargas/ Sobre grilhões e correntes/ Que no passado eram visíveis/ Sobre grilhões e correntes/ Que no presente são invisíveis/ [...]/Mas, irmão, fica sabendo/ Piedade não é o que eu quero/ Piedade não me interessa/ Os fracos pedem piedade/ Eu quero coisa melhor/ Eu não quero mais viver/ No porão da sociedade/ Não quero ser marginal/Quero entrar em toda parte/ [...]/ Eu quero o sol que é de todos/Ou alcanço tudo o que eu quero/ Ou gritarei a noite inteira/ Como gritam os vulcões/ Como gritam os vendavais/Como grita o mar/ E nem a morte terá força/ Para me fazer calar!" (Camargo, 1986, pp. 50-53).
} 
de Carlos Assumpção que, em memórias diversas, é considerado uma espécie de síntese daquele momento para uma fração cultural organizada do meio negro paulista.

O [Carlos] Assumpção se tornou uma espécie de portavoz de reivindicações que estavam escondidas dentro da Associação Cultural do Negro, descontentamentos: com o Treze de Maio, a tentativa de uma visão crítica de datas históricas... Tudo você vai encontrar no Protesto. $\mathrm{E}$, subjacente, aquela coisa: "Eu quero respeito, eu não quero piedade”. Na verdade, ele começa já a trazer a modernidade que vai aparecer na Literatura Negra. Que o Cuti vai trabalhar muito isso. Cuti, Paulo Colina, Abelardo Rodrigues [poetas dos anos 1970-1980] ${ }^{23}$.

A modulação discursiva dos versos de Protesto estará formatada aos seus diferentes públicos, ao final dos anos 1950: a) intelectuais que buscavam alguma autenticidade e especificidade da literatura negra no Brasil, como Sergio Milliet (1966); b) sociólogos que estão tentando observar alguma potência organizativa positiva nesse grupo social, como Florestan Fernandes; c) a própria ACN, cujo um dos pilares é a afirmação de uma respeitabilidade pública do grupo que representa; d) e, efetivamente, por fim, homens e mulheres negros, funcionários públicos, professoras, empregadas domésticas, balconistas dos comércios ou revisores de jornal, circulando por eventos da ACN e outras organizações ${ }^{24}$.

\footnotetext{
${ }^{23}$ Entrevista de Oswaldo de Camargo concedida ao autor em 29/07/2007, São Paulo.

${ }^{24}$ Carta de Carlos Magalhães Júnior, do Centro de Estudos Afro-Brasileiros de São Paulo ao Presidente da Associação Cultural do Negro, datada de 12/07/1958, em que convida a ACN para prestigiar conferência de Henrique Alves e leitura do poema de Assumpção. Coleção Associação Cultural do Negro, Acervo Ueim-UFSCar.
} 


\section{Entre 0 assistencialismo e a autodeterminação, 0 tema da integração do negro}

Encravada no centro da capital paulistana, a ACN assume, então, progressivamente, grau de importância, capaz de chamar atenção de uma parcela específica de intelectuais paulistas, com interesses circunstanciais ou mais duradouros.

No seu apogeu, [a ACN] chegou a ter mais de 700 sócios. Tinha entre seus afiliados membros hoje conhecidos, como o bibliófilo José Mindlin, os sociólogos Florestan Fernandes e Otávio [sic] Ianni. O penúltimo, inclusive, tornou-se o representante da entidade para fins culturais (Domingues, 2007).

Além disso, Oswaldo de Camargo se recorda que

De repente, eu por pertencer à Associação Cultural do Negro, que foi um momento importante, e lá estavam alguns autores: o Sérgio Milliet era um frequentador. $\mathrm{O}$ Affonso Schimidt, velhinho, já pouco antes de morrer, conheceu. [...] Aí eu conheço a Colombina [Yde Scholembach Blumenschein] na Associação Cultural do Negro. Ela frequentava quando havia efemérides, quando havia acontecimentos. Noite Luiz Gama, Noite Cruz e Sousa, Noite Auta de Souza [...] o Florestan Fernandes frequentava a Associação Cultural do Negro [...] estava sempre lá vendo tudo isso: Noite Cruz e Sousa, Noite Luiz Gama, Noite Nina Rodrigues [...] o prefácio [de 15 Poemas Negros] saiu porque o Florestan frequentava a Associação [...] Léon Damas veio ao Brasil e fez uma coletânea, uma antologia de poetas. Quer saber onde estão os poetas? Vá à Associação. [...] A Associação era o grande tambor que repercutia tudo. Era muito respeitada! Nenhum estudioso de questões negras deixava de ir à Associação [...] Basta 
dizer o seguinte. Não é muito difícil entender não. Correia Leite estava lá ${ }^{25}$.

Todavia, não foi apenas a eles que a ACN despertava curiosidade. Léon Gontran Damas, para organizar com poetas brasileiros a sua Nouvelle somme de poésie du monde noir, editada em francês, inglês, português e espanhol pela Présence Africaine (Damas, 1967), recorre àquele conglomerado de ativistas. Ali, segundo Camargo, toma conhecimento e recolhe os poemas de Natanel Dantas, Eduardo de Oliveira, Carlos de Assumpção, Luiz Paiva de Castro, Marta Botelho e do próprio entrevistado. Quase uma década antes, o poeta cubano Nicolas Guillén, a quem Solano Trindade dedicou um poema em Cantares ao meu povo, também já havia travado contato com alguns dos frequentadores da agora ACN - em particular Correia Leite. A centralidade desse ativista é algo que merece ser estudado, em outra ocasião.

Contudo, não apenas por intelectuais e escritores a ACN ou seus membros eram procurados. Criada como um fato político e cultural, por mais que seus mentores quisessem minimizar o primeiro adjetivo, ela se torna uma referência do ativismo negro, sendo chamada a emitir opinião ou se posicionar sobre os mais diversos assuntos, em diferentes momentos, acerca de questões que nem sempre pôde dar a resposta esperada.

Foi o que pensou, por exemplo, a Associação Beneficente Pio XII - entidade beneficente, fundada em 1956, que visava a "integração social e cultural da coletividade negra do Brasil" - ligada à igreja católica. Entre 1956 e 1959 (datação imprecisa, infelizmente, do documento disponível), ela envia correspondência à ACN, no sentido que essa seja uma das benfeitoras para aquisição de um Canal

${ }^{25}$ Entrevista de Oswaldo de Camargo concedida ao autor em 29/07/2007, São Paulo. 
de Rádio e TV, bem como da organização de uma "Universidade Afro-Brasileira" ${ }^{26}$. A Associação Beneficente Pio XII chega a formular um Plano de Integração Social e Cultural da Coletividade Negra do Brasil, com doze pontos visando o assistencialismo ao grupo negro ${ }^{27}$.

Não há notícia de que ele tenha sido levado a cabo. Entretanto, na entrada dos anos 1960, o tema da integração social e cultural do negro se torna, destarte, candente. É possível afirmar que existe, portanto, uma ambiência social para o que Florestan Fernandes desenvolveria naqueles anos, publicando mais tarde A integração social do negro na sociedade de classes, em 1964 (evidentemente, com sentidos e interesses diferentes, no âmbito sociológico, do assistencialismo religioso; ou mesmo do associativismo negro).

26 "Empenhei-me nesta campanha, que me preocupa desde 1935, em favor dos 20 milhões de pretos abandonados no Brasil. Pelo programa da obra, pretendo 248 habilitá-los à vida. Esmola é paleativo que não resolveria o problema [...] Peço a V. Excia. me auxilie a conseguir a Estação de Rádio e Canal de TV, como a organizar a Universidade Afro-Brasileira, números do programa que me possibilitarão levar avante a campanha [...] Quem se põe à frente de uma campanha, é forçado a lançar mão de todo recurso para vencer. [...] Dirigindo-vos esse apelo, em favor da integração nacional e cultural da coletividade negra no Brasil, penso nos 20 milhões de brasileiros que esperam ainda sua redenção econômica. Para acelerar a solução do problema [...] peço-vos a contribuição pessoal de Cr\$1.000,00, que unida às demais, possibilitará a aquisição do aparelho, a entrar imediatamente em atividade, levando o abençoado nome de São Paulo a todos os recantos do país" Excertos de cartas do Monsenhor Rafael Arcanjo Coelho para a ACN, s. d. Coleção Associação Cultural do Negro, Acervo Ueim-UFSCar.

27 “1) Promover o recenseamento da raça negra em todo o território nacional; 2) Normalizar a situação social e civil de todos os elementos da raça; 3) Organizar meios de subsistência e independência econômica para os elementos necessitados; 4) Conseguir com os governos da União e dos Estados glebas de terreno para nelas localizar as famílias negras necessitadas; 5) Possibilitar aos negros o acesso ao estudo médio e superior; 6) Criar o serviço de assistência social aos elementos da raça; 7) Criar e fomentar na raça a mentalidade de sua capacidade e independência; 8) Conseguir a solidariedade de todos para esta obra genuinamente nacional; 9) Criar a Rádio Beneficência Popular e conseguir canal de TV para propaganda deste programa; 10) Criar a Universidade Afro-Brasileira onde preferentemente estudem elementos da coletividade da raça negra; 11) Recrutar entre eles os elementos que colaborem nesta obra; 12) Criar o Banco de Crédito Negreiro, responsável pela manutenção do Plano". Plano da Associação Pio XII. Coleção Associação Cultural do Negro, Acervo Ueim-UFSCar. 
Tal ambiência pode ser pensada em chave tripla: I) do ponto de vista social mais abrangente, o interesse de setores da igreja católica com a questão racial e do negro marginal no pós-abolição; II) o debate, no âmbito das Ciências Sociais, acerca das temáticas de marginalidade e mudança social; III) a apropriação e discussão interna dos ativistas do grupo negro. Nos estatutos de fundação da ACN, de acordo com Petrônio Domingues, o tema da integração já aparece, aliado ao problema da marginalidade social. Os presentes à reunião criaram os estatutos para, entre outras razões, agregar pessoas naquela associação "que tivesse por finalidade fundamental a desmarginalização e recuperação social de todos os elementos que vivem em situação marginal, principalmente o negro" (Domingues, 2007).

Fragmentos da correspondência passiva e ativa da ACN revelam ainda que há articulações de entidades negras, local e internacionalmente, organizando-se num movimento pendular entre o assistencialismo e autodeterminação da figura do negro enquanto sujeito social, que se discutirá a seguir.

\section{África e cidadania como problemas (1960-1962)}

Como e por quê aparece a imagem do continente africano no imaginário dos ativistas e escritores negros em São Paulo, nos anos 1950 e 1960? Trata-se de um tema nebuloso. Um dos primeiros jornais da imprensa negra paulista, em 1915, se intitulava $O$ Menelik, em homenagem ao rei etíope Menelik II em sua guerra contra a Itália (Bastide, 1973; Ferrara, 1986). Igualmente nesses jornais, de acordo com Ferrara e Correia Leite, aparecem referências esparsas sobre aqueles temas africanos, dada a dificuldade de acesso à informação. Nos anos 1950, Luiz de Aguiar Costa Pinto (1998, p. 257) afirma ter ouvido, durante o Primeiro Congresso do Negro Brasileiro, relato sobre a penetração da ideia de negritude entre os intelectuais negros responsá- 
veis pelo TEN (Abdias do Nascimento, Ironides Rodrigues). Todavia, carece de maior pesquisa a circulação de imagens, ideias, literatura, cultura e situação política dos países africanos entre os intelectuais e ativistas negros brasileiros até a metade do século XX. No período posterior, a partir dos anos 1970, já é melhor documentada e compreensível (Alberti e Pereira, 2008; Silva, 2011).

No que diz respeito à ACN, seu acervo documental e depoimentos de seus integrantes permitem suscitar algumas rotas de entrada. Por ocasião do Segundo Congresso Mundial dos Escritores e Artistas Negros, que se realizaria em Roma, de 28 de março a 2 de abril de 1959, organizado pela Société Africaine de Culture (responsável pela Présence Africaine), a ACN formula carta para jornais, cujos excertos dizem o seguinte:

A "Société Africaine de Culture", ciente da importância 250 da contribuição dada pelo elemento africano à cultura do Brasil, acolheria com imensa satisfação uma representação de nosso país. Por isto, solicitou à Associação Cultural do Negro [...] para que [se] tornasse intérprete de tal desejo, pedindo outrossim divulgar as notícias referentes ao conclave e possivelmente tomar contato com o ambiente cultural do país, assinalando as figuras que dele desejam participar. Solicitamos então aos intelectuais negros e aos estudiosos eventualmente interessados no assunto, o envio de sua adesão, para que a ACN possa transmiti-la à "Société Africaine de Culture", recolhendo outrossim, os pormenores sobre a viagem para conhecimento daqueles que desejam participar do Congresso. [...] A "S.A.C", com a qual a Associação Cultural do Negro deseja estabelecer laços de amizade e de profícua colaboração, sugeriu também a criação no Brasil de uma associação "Amis de Présence Africaine”, com membros brancos e negros, objetivando estudar os problemas ligados à cultura afro- 
brasileira e a divulgação de todas as manifestações relativas a ela [...] A Associação Cultural do Negro, aproveita então esta oportunidade para lançar o seu apelo aos intelectuais brasileiros, negros e brancos, para que seja fundado em São Paulo um centro filiado à "S.A.C" digno de representar no estrangeiro a cultura africana no Brasil. Com este objetivo a A.C.N fará realizar dia 27 de fevereiro próximo, em sua sede social, uma reunião para tratar do assunto, estando desde já convidados todos os interessados [...] Finalmente, o senhor Alioune Diop, Secretário Geral da "Société Africaine de Culture", solicita o apoio e a solidariedade da intelectualidade brasileira, das associações culturais e das entidades que congregam o elemento negro, traduzidos no envio de mensagens por ocasião do congresso ${ }^{28}$.

Sarah Frioux-Salgas (2009, p. 12) esclarece que o projeto de Alioune Diop e do grupo da Présence Africaine, explicitado na carta acima, tinha ambições maiores, articuladas com notáveis em outras partes do mundo, o que torna muito significativo o contato com a ACN no Brasil, legitimando-a como sua interlocutora autorizada:

A rede de trocas e difusão de ideias imaginadas por Alioune Diop assume forma institucional depois de 1956, com a criação da Sociedade Africana de Cultura (SAC). Esta organização permitiria realizar certos objetivos postos aos agentes do Primeiro Congresso de escritores e artistas negros [...] Tratava-se de reunir os intelectuais e artistas negros do mundo todo engajados no combate pelo reconhecimento das culturas negras e da luta antirracista e anticolonial [...] Sua direção foi confiada ao etnólogo haitiano Jean Price-Mars. Josephine Baker pertencia ao

${ }^{28}$ Carta a jornais do vice-presidente da ACN, Américo Orlando da Costa, datada de 18/02/1959. Coleção Associação Cultural do Negro, Acervo Ueim-UFSCar. 
grupo de vice-presidentes. Encontram-se ainda no conselho executivo [...] muitas personalidade intelectuais e artísticas negras de diferentes gerações: os norte-americanos, com o músico Louis Armstrong, o sociólogo W. E. B du Bois, o cantor Paul Robenson, o poeta Langston Hughes, o escritor Richard Wright, a dançarina Catherine Dunham; os africanos: o ator Habib Benglia, os escritores Alexandre Biyndi (Mongo Beti), Amos Tutuola, Hampâthe Bâ, o cientista Cheikh Anta Diop; os antilhanos: o filósofo Frantz Fanon, os poetas Édouard Glissant e Aimé Césaire, o escritor René Maran, o ativista George Padmore; entre os malgaxes, o poeta Jacques Rabemananjara.

Consoante as memórias de Correia Leite, o então presidente da ACN "Geraldo Campos de Oliveira [...] tinha ido ao Segundo Congresso de Escritores e Artistas Negros realizado em Roma. Foi como observador. [...] [Ele] trouxe de 252 lá uma porção de documentos, teses e outras coisas" (Leite e Cuti, 1992, p. 177). Para viajar, Oliveira teve de fazer pedidos de concessão de passagens, em cortesia, à Panair do Brasil e Alitália ${ }^{29}$. Sendo a SAC responsável pela realização desse segundo congresso, deve-se notar que o esforço de Oliveira em viajar teve resultados.

No caminho da autoafirmação e determinação desses sujeitos sociais há também uma espécie de descoberta do continente africano, dentro da ACN, pela via cultural e política. O manifesto de 25 de março de 1960, quatro dias após o Massacre de Shaperville ${ }^{30}$, assinado por diferentes entida-

${ }^{29}$ Cartas de Geraldo Campos de Oliveira a Dr. César Pires de Carvalho, superintendente da Panair do Brasil e Dr. Francesco Trento, diretor superintendente da Alitália, datadas de 16/03/1959. Coleção Associação Cultural do Negro, Acervo Ueim-UFSCar. Notar as proximidades das datas, do pedido e da realização do congresso, 25/03/1959.

${ }_{30}$ Nome da cidade negra, localizada a 70 quilômetros de Joanesburgo, onde a polícia sul-africana, em 21 de março de 1960, executou um massacre ao abrir fogo contra cerca de 5 mil pessoas que participavam de um protesto pacífico contra a 
des em São Paulo, criticando as ações da União Sul-Africana faz com que haja um posicionamento da associação face ao que ocorria naquele continente e nos EUA. O documento dos ativistas deixa claro que:

As entidades e pessoas reunidas no memorável ato público promovido pela Associação Cultural do Negro, na sede da Associação Paulista de Imprensa, na noite de 25 de abril [sic] do corrente ano, e que subscrevem o presente manifesto, entendem que ninguém pode ficar indiferente aos clamores por liberdade, justiça e democracia, partidos das vítimas de massacre determinado pelo governo da União Sul-Africana [...] Os acontecimentos sangrentos de Shaperville, Langa e Carte Manor, representam o ressurgimento de tudo aquilo contra o que a Humanidade lutou duramente no último conflito mundial. O Mundo se encontra diante de uma absurda tentativa de restauração dos fundamentos ideológicos do nazifascismo, que são os fundamentos do "apartheid", com sua violenta negação do direito à liberdade, à igualdade, à justiça e à vida aos homens, mulheres e crianças negras sul-africanas. [...] A ONU não pode continuar permitindo [que] permaneça em seu seio, uma nação que pratica o genocídio e intranquiliza o Mundo, estarrecido diante de manifestações obscurantistas, características da Idade da Pedra Lascada [...] Aceitar de braços cruzados os atentados contra a Humanidade, cometidos na pessoa dos povos da África do Sul, é aceitar a regressão à barbárie [...] Por isso, com base nas convenções internacionais que o Brasil honradamente subscreveu [...] entendemos de apelar para o governo brasileiro, no sentido de que rompa definitivamente

Lei do Passe - que obrigava os negros da África do Sul a usarem uma caderneta onde estava escrito onde eles podiam ir -, matando 69 pessoas e deixando feridas outras 180. Considera-se que a brutalidade dessa ação chamou pela primeira vez a atenção da opinião pública mundial para o Apartheid. 
as relações diplomáticas e comerciais com a União SulAfricana, em defesa da Humanidade ${ }^{31}$.

Se, como afirma Correia Leite, "1960 foi considerado o Ano Africano [...] Aquela manifestação deixou os negros aqui entusiasmados" (Leite e Cuti, 1992, p. 177) ${ }^{32}$, é importante observar as ligações que se vão criando entre a ACN e outros organismos com igual interesse. A 9 de fevereiro de 1960, por exemplo, a União dos Caboverdeanos Livres, sediada em São Paulo, remete correspondência de agradecimento à Associação por seu pronunciamento contra a situação dos presos políticos das colônias portuguesas. Além disso,

vinha juntar as edições já publicadas do jornal "Portugal Livre”, órgão da oposição ao Governo de Salazar, em cujas colunas combatemos a tirania salazarista e procuramos mostrar ao Mundo Civilizado quanto esse governo representa de pernicioso para a Dignidade Humana ${ }^{33}$.

\footnotetext{
${ }^{31}$ Manifesto lançado pela ACN, 25/03/1960. Também subscrevem pessoas ligadas à Juventude Socialista, Frente Nacionalista de São Paulo, União Paulista de Estudantes Secundários, Teatro Experimental do Negro de São Paulo, Centro Acadêmico João Mendes, Federação dos Professores e Trabalhadores em Est. de Ensino etc. Coleção Associação Cultural do Negro, Acervo Ueim-UFSCar.

${ }^{32}$ E ainda: "A Associação Cultural do Negro chegou a fazer um ato de protesto contra a discriminação racial na África do Sul e na América do Norte, onde estava sendo iniciada a luta pelos direitos civis. Nesse ato da Associação também foi evocado o problema africano geral e sugerida a ideia de se criar um comitê de solidariedade aos povos africanos. Creio que essa proposta deve ter chegado à África portuguesa, pois nós passamos a receber publicações do Movimento Popular para Libertação de Angola, não endereçado à Associação, mas ao Comitê de Solidariedade aos Povos Africanos. Mas esse comitê, devido à falta de elemento humano, com disposição para trabalhar, não se formou" (Leite e Cuti, 1992, p.175, grifos meus).

${ }_{33}$ Carta de Guilherme Morbey Rodrigues, presidente da União dos Caboverdeanos Livres a Américo Orlando da Costa, vice-presidente da ACN, datada de 09/02/1960. Coleção Associação Cultural do Negro, Acervo Ueim-UFSCar. Sobre Portugal Livre e a resistência antissalazarista em São Paulo, ver Silva (2000).
} 
Internacionalmente, portanto, a questão africana e segregação estadunidense se tornam um tema de interesse para uma fração dos negros associados, naquele momento. Inclusive, um tópico chamativo até mesmo literário, apreciado como uma grande novidade pelo ilustre desconhecido - embora muito falado - continente africano, como afirma Oswaldo de Camargo:

Naquele tempo, não. Você não conhecia a África. A África que você tinha era a África literária. Que foi traduzida por "Navio negreiro" [...] [no] meu poema, "Meu grito", eu pergunto: "Oh, África! Oh, África!”’34. É um desconhecimento. A África que nós temos é uma África mítica. É uma África de gravuras. [...] De repente que começam [...] Vamos situar em 1960. Este jornal... [Niger] eu sou o editor-chefe dele. [...] Então, a capa do Níger aqui é o Patrice Lumumba. Então, a África começa a se agitar. Começa a começar o movimento de independência na África. Esse movimento de independência da África, vai colocar a África, dar uma visibilidade maior, desperta o interesse por gente... Aí chegam de Angola alguns rapazes que chegam refugiados, vieram refugiados da África, de Angola, falando português. Tanto que nos espantava o sotaque lusitano deles. Eram dois, pelo menos. Um deles era o, me lembro muito bem, Paulo Matoso. Eles vêm com alguns livros africanos. Primeira vez que nós vimos alguns livros vindos da África! Primeira vez, pelo menos para mim, que eu deparo, que eu topo um africano. Um homem negro africano. Para mim, o início de conhecer a África foi aí. E foi mediante o Paulo Matoso, que me deu um livro da Noêmia [Carolina Abranches de Souza Soares] - deu não; emprestou um livro da Noêmia, que era uma poetisa de Moçambique ou Angola, não vem ao caso agora - eu

\footnotetext{
${ }^{34}$ Esse poema foi editado em Camargo (1961).
} 
talvez seja um dos primeiros autores que escreveu sobre um poeta africano, no Novo Horizonte. [...] Porque daí começam também Angola, movimento em Moçambique, Angola... Isso repercute aqui. Até pela leitura dos jornais em geral. Os jornais em geral começam a falar sobre isso. Porque, na verdade, o que nós conhecemos melhor, nesse momento, são os autores americanos. É natural. Por que? O cinema americano trata do negro. As traduções que chegam: Filho nativo [de Richard Wright], Langston Hughes... Richard Wright, Langston Hughes, chegam aqui. A gente vai lendo o pouco que chega. A Rua [Ann Petry], Donos do orvalho [Jacques Roumain], que está lá, do René Maran... São livros que todo mundo, todo negro que se preza como intelectual procura ler esses livros. É aquela leitura que é leitura de turma. Você tem que ler, senão não é da turma. Duvido que algum negro candidato a escrever, na época, não tivesse lido, não tenha lido o Filho nativo ${ }^{35}$.

Além de se pronunciar politicamente, a ACN, cujos principais líderes e mentores se opunham à exclusividade de uma associação negra ser meramente festiva ou de convescote, decide dar prosseguimento à organização de sua Série de Cultura Negra, iniciada em 1958, após a comemoração do Ano 70. Na sequência da publicação de 15 poemas negros, saem dois livros de Henrique Losinkas Alves (Cruz

\footnotetext{
${ }^{35}$ Entrevista de Oswaldo de Camargo concedida ao autor em 29/07/2007, São Paulo. Paulo Matoso, estudante e jornalista angolano. Acerca dele, há poucos dados informativos. Sabe-se que fez a revisão geral de Banzo de Eduardo Oliveira, poeta negro paulistano (ver Oliveira, 1963), que tinha ligações com o MPLA (Movimento pela Libertação de Angola) e com o MABLA (Movimento Afro-brasileiro pela Libertação de Angola), sendo preso em 1964 (ver Santos, 2010). Já Noêmia Carolina Abranches de Sousa Soares (1927-2003) é moçambicana, tendo estudado no Brasil e trabalhado em Lisboa, de 1951 a 1964, quando se exilou na França, devido à sua contestação ao governo de Salazar. Poeta e jornalista, ela engajou-se nas lutas de libertação nacional africana, publicando artigos e viajando por diferentes países daquele continente. Todos os jornais da imprensa negra paulista criados no interior da ACN - Niger, Novo Horizonte, e Mutirão-, tiveram vida curta, de acordo com Miriam Ferrara (1986) e Leite e Cuti (1992).
} 
e Souza: o Dante negro e Nina Rodrigues e o negro no Brasil, publicados, respectivamente, em 1961 e 1963) e um de Nestor Gonçalves (Fatores determinantes da cultura afro-brasileira, lançado em 1962). A tentativa de se fazer uma série se estanca, contudo, no quinto número. Observa Camargo que "A Associação não tinha dinheiro para isso. Mal conseguia pagar aluguel, essa é a realidade. Quem bancava isso era o próprio autor, geralmente. A não ser que ele achasse alguém que bancasse no lugar dele" 36 .

A dificuldade das condições de manutenção dos projetos da ACN não obstou, entretanto, a intenção de realizá-los ou as demandas que lhe chegavam até os primeiros anos da década de 1960. As comemorações do centenário de Cruz e Sousa são um exemplo disso. No relato de José Correia Leite sobre o assunto, percebe-se, duplamente, o esforço coletivo empreendido por membros da associação preocupados com a questão cultural (não raro, sintetizada pela literatura) bem como a importância que a ACN conferia aos grandes feitos e aos grandes nomes.

Mas o mais importante deste ano foi quando nós estudamos fazer o medalhão de Cruz e Sousa e colocar em praça pública. Conseguimos um escultor que não cobrou nada para fazer o medalhão, só cobrou o material. [...] Acabamos escolhendo uma pedra bruta, barata. Daí foi a hora de saber da prefeitura como é que a gente devia proceder para colocar em praça pública. O Henrique L. Alves [...] Foi falar com o doutor Freitas Nobre, então vice-prefeito [...] [que] foi à Associação e começou a fazer uma porção de objeções, achando que o medalhão era muito pobre, dizendo que por ele o medalhão estava desaprovado. Mas ele não podia dar a última palavra [...]. O prefeito era o Prestes Maia. Nós conseguimos descobrir um oficial de gabinete do prefeito,

${ }^{36}$ Entrevista de Oswaldo de Camargo concedida ao autor em 29/07/2007, São Paulo. 
um tal de doutor Galo. Falamos com ele e ele, com a melhor boa vontade, resolveu o assunto e o local escolhido ficou sendo a Praça Dom José Gaspar, ao lado da biblioteca municipal [...] O Henrique L. Alves se incumbiu de levar a matriz em gesso do medalhão para a Academia Brasileira de Letras e, nesse ensejo, convidou o doutor Austregésilo de Athayde para vir a São Paulo inaugurar o medalhão, embora muita gente do meio intelectual não acreditasse que ele viesse. Mas ele aceitou o convite. [...] O medalhão ficou pronto para ser inaugurado à tarde, como de fato aconteceu. A boa vontade do presidente da Academia Brasileira de Letras foi demonstrada pela maneira como ele veio, de trem, com sua senhora [...] E ele foi à Associação e viu a simplicidade da nossa sede. [...] Na Praça Dom José Gaspar estava um número pequeno de negros e brancos, inclusive o Florestan Fernandes, que tinha sabido do evento na véspera, e o diretor da biblioteca que é ali do lado [...] 258 Eu comecei a sentir que o doutor Austregésilo de Athayde estava constrangido. Porque uma festa daquela ninguém vai olhar quem está promovendo, se é uma entidade de alto nível cultural ou uma entidade de classe mais baixa. [...] Mas, é de se lamentar que não tenha comparecido ninguém da Academia Paulista de Letras, da União Brasileira de Escritores ou do Instituto Histórico e Geográfico. Todas essas entidades receberam convites da Associação Cultural do Negro [...] A nossa sorte é que a sessão da Banda da Força Pública estourou num toque de continência e desceu dum carro o vice-governador Porfírio da Paz, que foi assistir à inauguração. Aquilo deu uma nova alma ao presidente da Academia, que fez um discurso muito inflamado [em que afirma que] se tratava de uma entidade de gente pobre, sem a importância de letrados, mas pondo em brios os intelectuais do Brasil que iam deixar passar em brancas nuvens um evento tão importante como aquele. Depois ele [...] pediu desculpas em nome da Academia Brasileira de Letras, pelo erro de não 
ter sido o Cruz e Sousa colocado no rol dos fundadores da academia (Leite e Cuti, 1992, pp. 188-189).

Esse último longo relato de Correia Leite sobre como se dá a inauguração do monumento a Cruz e Souza (hoje destruído ou desaparecido ${ }^{37}$, na praça Dom José Gaspar, ladeando a Biblioteca Mário de Andrade com os bustos de Camões e Dante, é exemplar na síntese do esforço coletivo empreendido por uma fração cultural negra em São Paulo. A rememoração desse evento por Correia Leite denota a preocupação de setores da ACN em positivar imagens e figuras do passado, cristalizando suas memórias e demonstrando as contribuições do grupo negros em variados setores. Isso foi feito com o monumento à Mãe Preta, com o Poeta do Desterro, o abolicionista Luiz Gama e com Carolina Maria de Jesus, autora de Quarto de despejo, um sucesso de vendas lançado em 1960.

O Ano Cruz e Souza também demarca outras iniciativas para as quais a ACN é acionada, evidenciado alguma efervescência no biênio 1960-1961. Por exemplo: em 1961, a agente viagens (tour manager) Estela Grunebaum envia correspondência à associação afirmando que:

Temos recebido de nosso correspondente dos Estados Unidos várias cartas, com referência consulta sobre vindas ao Brasil de grupos e pessoas individuais de homens de cor dos Estados Unidos [...] O desejo destas pessoas é vir ao Brasil para intercâmbio de ideias e confraternização com os associados daqui, e portanto, gostaríamos de saber quais os programas que poderiam oferecer aos vossos irmãos do Norte, a fim de que possamos recepcioná-los bem $[\ldots]^{38}$.

\footnotetext{
${ }^{37}$ Desde 2002 ou 2003, o monumento a Cruz e Souza foi vandalizado, não tendo sido restituído no local (Villa, 2004, p. A3; Abreu, 2003, p. 5).

38 Carta de Estela Grunebaum aos Exmos Srs. Da Associação Cultural do Negro, 29/08/1961. Coleção Associação Cultural do Negro, Acervo Ueim-UFSCar.
} 
O estado das fontes só permite supor qual o grau de excitação e apreensão causou semelhante missiva. "Era uma associação pobre, constituída majoritariamente de funcionários e empregadas, raramente de professores”, já havia dito Oswaldo de Camargo. A fração cultural interna era minoritária. Não há notícia, nas memórias de Correia Leite ou nas fontes pesquisadas em arquivo que, no caso de terem vindo, os "irmãos de cor do norte" tenham efetivamente passado pela ACN e sido "recepcionados bem". Todavia, o conjunto de ações empreendidas anteriormente por aqueles homens e mulheres os colocou num ponto significativo de um mapa de visibilidade e importância social, vistos como um ponto de referência, aos olhos de outros sujeitos interessados em aspectos da vida do negro, ao menos em São Paulo. No rodapé da carta, alguém da associação escreveu um esboço de resposta a Grunebaum, que deveria conter um programa social, cultural e profissional da ACN. Não há 260 menção, nos arquivos, sobre o envio da mesma.

Até 1964, portanto, um conjunto de ações e intenções de destaque vão conformando o caminho da ACN e de outras organizações negras em São Paulo, que podem ser descritas através da documentação. Em 1961, por exemplo, a Irmandade de Nossa Senhora do Rosário dos Homens $\operatorname{Pretos}^{39}$, através de seu então presidente, Raul Joviano do Amaral, anuncia que no dia 15 de outubro daquele ano,

O Departamento Hospitalar da Irmandade de Nossa Senhora do Rosário tem a satisfação de convidar Vv. Ss. [...] a fim de prestigiarem com Vv. honrosas presenças o lançamento da pedra fundamental do futuro "HOSPITAL NOSSA SENHORA DO ROSÁRIO”, a ser realizado

\footnotetext{
${ }^{39}$ Sobre a Irmandade, ver Amaral (1991) e Quintão (2002). Consultada, a secretaria da igreja, localizada no largo do Paissandu, em São Paulo, não soube confirmar a informação deste documento ao pesquisador. E os trabalhos citados não tratam do assunto, referindo-se a período anterior na trajetória da Irmandade do Rosário.
} 
às $11 \mathrm{~h} 20$, no dia 15 de outubro, no terreno situado à av. Marginal Esquerda, junto à Ponte da Vila Maria [...] Na oportunidade será consagrado e inaugurado valioso "CRUZEIRO", confeccionado em madeira de lei, testemunhando as melhores esperanças na conclusão de obra destinada a bem servir a coletividade e a enriquecer o sistema médico hospitalar do país ${ }^{40}$.

Embora haja atualmente um Hospital Nossa Senhora do Rosário, na Vila Maria, em São Paulo, não há informação sobre sua ligação com a Irmandade do Rosário dos Homens Pretos. Talvez o hospital tenha sido erigido e essa ligação se perdeu, por diferentes motivos. O fato importante é a intenção presente na ação. Uma irmandade beneficente, de corte étnico, existente desde 1711, e que se ocupa de tentar criar um hospital direcionado ao grupo negro - assim como ocorreu a outros grupos migrantes: portugueses, sírios-libaneses, italianos, israelitas, nipônicos. É um passo ousado, em que as dificuldades seriam grandes, certamente (arrecadar fundos interna e externamente, médicos e enfermeiros, manutenção do hospital, escapar da acusação de racismo às avessas etc.).

Mas possuiria fundamentos mais concretos e imediatos, para alguns militantes como José Correia Leite, por exemplo, que a tentativa de ser organizado um Congresso Mundial da Cultura Negra em São Paulo, como se daria no ano seguinte. Em maio de 1962, a Comissão organizadora dessa iniciativa enviou comunicação à ACN. Estava associada à Associação Beneficente Pio XII e fazia saber que

Temos a elevada honra de apresentar a V. Excia. o anexo, programa das solenidades comemorativas do dia 13 de

\footnotetext{
${ }^{40}$ Ofício n. 16-A, da Irmandade de Nossa Senhora do Rosário dos Homens Pretos, assinado por Raul Joviano do Amaral, ao Presidente da ACN, 06/10/1961. Coleção Associação Cultural do Negro, Acervo Ueim-UFSCar.
} 
maio, no Parque São Domingos, Lapa, às 8,30 [...] e no Teatro Municipal às 20 horas[...] primeiro número oficial com que a Comissão Organizadora do 1 Congresso Mundial da Cultura Negra e a Associação Beneficente Pio XII festejam o lançamento simbólico do "Encontro Estadual”, da instalação da Rádio Educadora Popular e a visita à Exposição da Maquete da Universidade AfroBrasileira, tendo em vista o aludido Certame Cultural pretendendo porem-se em contato com a sociedade paulistana, para a evolução de seu programa beneficente da coletividade negra do Brasil ${ }^{41}$.

Era do interesse dos organizadores que as cerimônias de Treze de Maio preparassem um "'Encontro Nacional' que se dará em novembro deste ano, tendo em vista o 1 Congresso Mundial da Cultura Negra, pondo diante dos novos olhos a realidade da situação". A "realidade da 262 situação" seria a precariedade das condições de vida do grupo negro em São Paulo e a necessidade urgente de setores da sociedade fazerem algo. Lembre-se que dois anos antes, no entanto, Quarto de despejo: diário de uma favelada, de Carolina M. de Jesus (1960), já havia colocado semelhantes temas no centro das discussões. Todavia, os organizadores da solenidade, independentemente disso, estabeleceram o seguinte programa do Congresso, datado de 13 de maio de 1962 e anexado ao convite acima, se iniciava com:

6 h30 - Missa de ação de graça oficiada pelo Monsenhor Rafael Arcanjo Coelho, diretor e fundador da Associação Beneficente Pio XII. [...] 8h45 - No Parque São Domingos, Lapa, ao lado dos terrenos da futura Universidade AfroBrasileira, recepção às autoridades: Dr. Tancredo Neves, $1^{\circ}$

\footnotetext{
${ }^{41}$ Convite do Primeiro Congresso Mundial da Cultura Negra. Coleção Associação Cultural do Negro, Acervo Ueim-UFSCar.
} 
Ministro, Dr. Carvalho Pinto, Governador do Estado, Dom Carlos Carmelo de Vasconcellos Motta Cardeal Arcebispo Metropolitano de S. Paulo, e outras personalidades ilustres [...] Palavras de Saudação pelo Snr. Eduardo de Oliveira, às autoridades e aos presentes em geral [...] Palavras do Snr. Paulo dos Santos Matoso Netto em nome dos Bolsistas Africanos. Srta. Ana Florença de Jesus, agradecendo os que cooperam para a realização do 1 Congresso [...] 20h30 - No Teatro Municipal, realização de um Concerto pela Banda Sinfônica da Força Pública do Estado, precedido de uma Conferência a cargo do Prof. Dr. Florestan Fernandes, da USP, cujos convites se encontram na bilheteria do Teatro.

"O orador oficial dessa solenidade foi o professor Florestan Fernandes. Ele fez uma conferência sobre o Movimento Negro em São Paulo e, por várias vezes, citou o meu nome. Eu não estava presente porque não fui convidado" (Leite e Cuti, 1992, p. 191), conclui José Correia Leite irritado com o fato, já que não concordava com a realização do congresso, por achá-lo dispersivo e fora de propósito aos interesses que julgava importantes ao grupo negro em São Paulo.

\section{Alcances e limites do associativismo negro: os testes da realidade social, 1962-1964}

Os passos dados até aqui, exemplificados nas ações anteriores, haviam sido extremamente largos. Apenas palavras não seriam mais o bastante para a concretude das intenções. Algum lastro mais efetivo que os simbolismos dos atos, discursos, convites, pessoas envolvidas etc. deveria apoiar as ações da fração organizada negra em São Paulo. Poetas, jornalistas e ativistas negros, orbitando a ACN, com suas intenções mais progressistas e suas exposições de uma visão social de mundo objetivando integração, equidade e respeito teriam que passar por alguma espécie de "teste da reali- 
dade", em sua faceta mais dura: das possibilidades concretas, nos termos almejados, de inclusão e reconhecimento plenos na sociedade envolvente, capazes de efetivar a emancipação e o ideal de uma Segunda Abolição.

Relações com intelectuais negros africanos, europeus ou estadunidenses; ligações com ativistas e intelectuais da metrópole paulistana não negros; um hospital beneficente; Série Cultura Negra; Ano 70 da Abolição, Congresso Mundial de Escritores Negros, Ano Cruz e Souza, Congresso Mundial da Cultura Negra etc.: aonde tudo isso iria levar o grupo negro organizado paulista? Estaria ele já pronto para o teste da realidade social, da mudez e obstaculização provocados pelo racismo e marginalidade aos seus objetivos? E essa, a realidade, estaria pronta para reconhecê-lo da maneira que era inquirida nas ações, poemas, ideias gestadas e proferidas em sessões solenes, reuniões, atos, cartas, ofícios, posicionamentos?

264 Os anos subsequentes demonstraram que não. Se o protesto e a revolta são enunciados por uma fração organizada negra - e bem recebidos, igualmente, por uma fração cultural não negra - com força em quase uma década de atuação político cultural, o desafio de conferir alguma concretude maior aos feitos caminhava justamente para alcançar círculos cada vez mais amplos. Entretanto, isso demandaria um esforço de realização e compreensão do objetivo cada vez maiores, por negros e não negros, sensibilizados por aqueles ideais. Todavia, o fim da ACN se mostrou problemático, bem como daquele tipo de organização negra em São Paulo. José Correia Leite e Oswaldo de Camargo o enunciam claramente, demonstrando os alcances e limites que foram possíveis àquela fração político cultural organizada almejar.

houve um litígio entre a Associação e o proprietário do conjunto. Mas antes de terminar, houve um esforço de um grupo de moços. Um era professor de inglês, outro formado 
em agrimensura e ótimo em matemática, e apareceu também uma alemã, Dona Dóris, que se propôs a dar aulas de inglês, no sentido dela poder aprender melhor o português, mas infelizmente os alunos não puderam devolver a ela o que ela queria receber em troca. Ela acabou desistindo depois de ter tentado também fazer uma ópera de Mozart adaptada para artistas negros [...] Teve uma ocasião em que apareceu um pianista. Queria fazer um recital e demonstrou para nós que tipo de espetáculo que seria [...] Mas ele só deu aquela demonstração e, como viu que nós não tínhamos condições de fazer o espetáculo como ele queria, não voltou mais. Não tínhamos realmente condições de empresariar espetáculos [...] Quando eu dei pela coisa já era mil novecentos e sessenta e cinco. Eu tinha completado meu tempo de serviço na prefeitura e entrei com meu pedido de aposentadoria. Aí resolvi me aposentar também da minha militância e acabei me afastado da associação. [...] Não passou muito tempo eu soube que a Associação tinha fechado. Soube também que um grupo, tendo uma senhora advogada [...] o Eduardo de Oliveira e Oliveira e outros, tinha levado a Associação para o bairro da Casa Verde [...] Na Casa Verde a Associação tentou funcionar, mas não conseguiu (Leite e Cuti, 1992, pp. 192-194) ${ }^{42}$.

Para além dos problemas internos (dificuldade para pagar contas e falta de apoio dos associados), o teste mais duro da realidade envolvente é o golpe civil militar de 1964: desmobiliza o que já era precário, amedronta os que tinham

42 O período 1965-1976 corresponde à etapa da ACN no bairro da Casa Verde em São Paulo, coordenada pela advogada Glicéria de Oliveira e o sociólogo Eduardo de Oliveira e Oliveira. Caracteriza-se por uma atuação modificada, valorizando a interação com a comunidade do bairro, criando cursos de alfabetização, por exemplo. Infelizmente, não se poderá tratar dessa nova fase aqui, com a profundidade e cuidado que ela merece. 
dúvidas, inviabiliza os tênues amparos que a ACN conseguiu estabelecer com intelectuais e pessoas, notadamente progressistas e, algumas, de esquerda. Exemplo disso, é a trajetória que assumirá Florestan Fernandes, o intelectual mais próximo da associação, pós-golpe: cassado, exilado, incapaz de ajudar pouco além de si mesmo (Sereza, 2005). Outro é angolano Paulo dos Santos Matoso (Santos, 2010). De acordo com Márcio Moreira Alves,

Após o golpe militar do 1o de abril de 1964, no País, todos os estudantes africanos das colônias portuguesas, aqui residentes, foram presos. A maior parte desses estudantes, o Ministério das Relações Exteriores havia assegurado permanência no País como bolsistas. A 1o de agosto de 1964 era preso outro nacionalista angolano, Paulo dos Santos Matoso, que era trazido de São Paulo para depor no Inquérito Policial Militar (IPM do Grupo Angolano), nome atribuído pelos militares ao processo com que pretenderam condenar os patriotas angolanos (Alves, 1996, pp.183-184).

Após o biênio 1962-1963, não há registros interessantes referentes à ACN para essa fase. Seu momento áureo, concordam Clóvis Moura e Petrônio Domingues, se encerra no pré-1964, com crises financeiras cada vez mais agudas. O primeiro afirma que, na busca de se criar uma ideologia para o grupo negro paulista, surgiram contradições e embates internos, que culminariam em desordem financeira (Moura, 1983, p. 158). Refere-se a confrontos entre grupos que pensavam a ACN com diferentes inclinações face à ideia de cultura: política de afirmação e reconhecimento ou divertimento e assistencialismo. O primeiro grupo era minoritário, como reafirma Oswaldo de Camargo, numa ilustração amarga: 
O piano que lá estava [na sede] era um piano emprestado, por uma moça chamada Marta. Quando a Marta ofereceu [...] para nós ficarmos com o piano, a um preço baixíssimo, e não pudemos ficar, aí foi que eu saí da Associação. De revolta. Em lugar do pessoal pegar o dinheiro para comprar o piano, pegaram o dinheiro para o esporte. Me deu um desalento muito grande. O piano era importante ali. Então, a Associação passava por percalços bem humanos, de falta de dinheiro, deserção de gente que não via aquilo como ideal etc. ${ }^{43}$

O outro teste da realidade pode ser atribuído à crise do associativismo negro no século XX, fazendo surgir e desaparecer rapidamente distintas organizações, de importâncias consideráveis. Nas memórias de José Correia Leite são enunciadas várias delas, algumas das quais ele próprio ajudou a criar. Entretanto, ao depender do impulso e carisma de alguns sujeitos, a comunhão do ideal se prejudica, obstando assim a perenidade das ações e organizações, mesmo em situações adversas.

Um prospecto, nos arquivos da ACN em São Carlos, mostra o desenho feito por Clóvis Graciano para o primeiro número da Série Cultura Negra (1958), referente ao Ano 70. Acima dele está escrito "Mês da Abolição". Na contra página, o imperativo "DIGA QUE A ACN É UMA FORTALEZA". Entre o dito e o fato, existe uma distância considerável, como concluiu Domingues: "Sem recursos para saldar as várias dívidas, a entidade foi obrigada a fechar suas portas em 1967. Quase dois anos depois, foi reaberta, mas sem o mesmo perfil e poder de articulação. Nessa nova fase foi presidida por Glicéria Oliveira e passou a desenvolver ações de cunho assistencialista, com cursos de alfabetização e madureza" (Domingues, 2007, p. 6).

${ }^{43}$ Entrevista de Oswaldo de Camargo concedida ao autor em 29/07/2007, São Paulo. 


\section{Auxiliada pelo sociólogo Eduardo de Oliveira e Olivei- $\mathrm{ra}^{44}$, Glicéria conduz a ACN numa fase crítica, em que, após o despejo do edifício Martinelli, ocorre a mudança para a Casa Verde, em 1975. Um ano depois, a associação fecha as portas, doando móveis e documentações para terceiros, como atestam os "Instrumentos particulares de doação e transferência" assinados pela presidente da entidade, em 5 de julho de 1976. No mesmo dia, Glicéria Oliveira enviou}

${ }^{44}$ Em entrevista a Conrado Pires de Castro, afirma o sociólogo José de Souza Martins: "Foi de minha turma e foi meu amigo Eduardo de Oliveira e Oliveira, intelectual refinado e culto, mulato, dos meus conhecidos e amigos o que melhor compreendia as gradações e as implicações da diferenciação social naquele estranho e fascinante mundo da Faculdade de Filosofia da rua Maria Antônia, perto da qual morava. Ele era filho de um estivador negro do porto do Rio de Janeiro, que se tornara líder sindical e, como ele mesmo dizia, pelego do trabalhismo de Vargas. Eduardo tivera a melhor educação que alguém podia receber em sua época no Rio de Janeiro. De vez em quando, seu pai embarcava-o na limusine de seu uso e dava um passeio pelas docas, mostrava-lhe os estivadores que carregavam nas costas pesada sacaria e lhe fazia esta advertência: 'Não se esqueça nunca de que o que você é e virá a ser deve a essa negrada'. Eduardo não esqueceu. De vez em quando convidava seus amigos negros e vários de nós, que vínhamos 'de baixo', e também alguns professores, artistas e intelectuais para uma mesa de queijos e vinhos finos em seu apartamento para, no estilo das velhas famílias, um sarau de conversação culta. Organizou para negros do bairro da Casa Verde uma escola, para a qual convidava professores da USP, com razão convencido da função emancipadora dessa ressocialização. Escreveu uma peça teatral emblemática, a cuja estreia compareci, sobre as contradições e as armadilhas da ascensão social no meio negro - e, agora, falamos nós -, dirigida e apresentada no Teatro do Masp por sua amiga, a atriz Teresa Santos. O título da peça foi inspirado num incidente ocorrido, que presenciei, no prédio de Filosofia e Ciências Sociais, na Cidade Universitária. Eduardo organizara um seminário sobre o negro, numa das salas, para o qual convidara vários professores da Faculdade de Filosofia e vários negros. Uma das professoras, ao terminar sua exposição, que foi a primeira, explicou que precisava se retirar, pois tinha outro compromisso. Ela já estava na soleira da porta quando Eduardo pediu-lhe que voltasse, pois tinha algo importante a dizer. E disse mais ou menos o seguinte: "Nós (negros) passamos séculos ouvindo vocês. Quando chega a hora de falarmos, vocês dizem que não têm tempo para nos ouvir". Ela ficou muito embaraçada com a interpelação inesperada, desculpou-se, disse que não era nada daquilo e foi embora. Desiludido com o oportunismo e a precedência das aspirações de ascensão social e de branqueamento dos negros que o cercavam no projeto da Casa Verde, Eduardo suicidou-se, deixando-se morrer de fome e sede, trancado em seu apartamento, a alguns passos da velha Faculdade de Filosofia" (Castro, 2010, pp. 239-240). A escola a que Martins se refere é a transferência da sede da ACN para a Casa Verde. O acervo de Eduardo de Oliveira e Oliveira se encontra na Ueim-UFSCar. 
carta notificando os membros remanescentes da ACN acerca do encerramento das atividades da associação. A ela respondeu o bibliófilo e empresário José Mindlin, em papel timbrado de sua indústria, a Metal Leve, na missiva citada abaixo, digna de nota e perguntas: ele e outros membros poderiam ter ajudado, ao menos, na crise financeira? $\mathrm{Ou}$ o projeto já tinha se esboroado, a ponto de não contemplar mais apoios? Que grau de vinculação ou de alcance colaborativo, de fato, possuíam os membros não negros da associação? Nessa nova fase, que identificação haveria, entre os membros negros e não negros, com os projetos atuais da ACN?

Prezada Senhora [...] Recebi sua carta de 5 do corrente comunicando-me o encerramento das atividades da Associação Cultural do Negro, e só posso dizer que lamento profundamente que os amigos tenham sido levados a uma tal decisão, pois a Associação vinha fazendo um trabalho extremamente útil e meritório. [...] Se as dificuldades que vocês atravessaram não lhes tirarem totalmente o ânimo e vocês decidirem partir para alguma outra iniciativa semelhante, podem contar com a colaboração que esteja ao meu alcance ${ }^{45}$.

José Correia Leite tem razão em afirmar que, até aquele momento, "a ACN foi a que teve vida mais longa entre as entidades que existiram com a finalidade de realizar uma obra de levantamento histórico e social do negro" (Leite e Cuti, 1992, p. 195). Longeva, porém esquecida. Tratou-se de um empreendimento coletivo surgido, simultaneamente, da adversidade e necessidade históricas (o IV Centenário e a necessidade do "elevamento" do negro, da crítica e posicionamento contra sua marginalidade), capaz de enga-

${ }^{45}$ Carta de José E. Mindlin a Glicéria Oliveira, 30 de jul. 1976. Coleção Associação Cultural do Negro, Acervo Ueim-UFSCar. 
jar num curto intervalo um conjunto de homens e mulheres, suas ideias e energias, em torno de uma missão comum. Depois da Frente Negra Brasileira, é o empreendimento político cultural mais notável, sem fim religioso ou apenas recreativo, do negro em São Paulo, até meados da década de 1970, antecedendo a reorganização do Movimento Negro, a partir de 1978. Dela surgiu, por exemplo, o Cecan em 1976 e, através de alguns de ex-membros da ACN, se daria a contribuição para a fundação dos Cadernos Negros (publicação literária editada desde 1978 até os dias correntes). Os novos agentes do Movimento Negro Brasileiro, em São Paulo, em alguma medida recorreram à experiência pregressa das antigas organizações, mesmo que para tentar não repetir seus equívocos, dentre as quais, a ACN.

Na tensa relação de fazer história e fazer sentido, a ACN procurou marcar um lugar importante para o grupo negro paulistano, tentando se por em compasso com o andamento 270 das transformações da sociedade, abrindo uma brecha, às suas custas e às expensas de poucos apoios de alguns intelectuais não negros, para cravar no cenário da modernidade precária emergente de São Paulo, uma imagem do negro alternativa à da escravidão, que fosse reivindicativa, crítica, propositiva e combativa. Os condicionamentos sociais para sua produção foram determinantes para reafirmar a marginalidade da iniciativa cultural negra, embora tenha sido capaz de, fato raro, alçar um público não endógeno, num momento favorável, em aberto, com disposições democráticas.

Correndo por fora e forçando a sua visualização num lugar diferente do secundário e marginal, os ativistas, intelectuais e escritores negros estavam em pugilo, em diferentes patamares, com a realidade social. Ela os desafia e os testa, na mesma medida em que eles executam ação semelhante. Nesse movimento, se desenvolve uma luta social, composta de ações práticas (atos, eventos, comemorações) e gestações de ideias-força (negritude, descoberta do con- 
tinente africano, poemas etc.) que explicitam a tensa situação do grupo negro paulistano em meados do século passado. Embora beire à teleologia frente a uma história de rastros e escombros, não se pode furtar a inquirir aonde tudo teria levado, com sucesso, o grupo negro organizado. Se não conseguiram ir além, pelos diversos motivos apontados anteriormente, não pode ser desprezado o que se logrou fazer e se ousou propor.

\section{Mário Augusto Medeiros da Silva}

é doutor em Sociologia pela Unicamp.

\section{Referências bibliográficas}

ABREU, I. E. 2003. "Vandalismo cultural: raiva e crime". Jornal da UBE, no 103, p. 5 .

ABUD, K. M. 1985. O sangue itimorato e as nobilíssimas tradições. A construção de um símbolo paulista: o bandeirante. Dissertação de mestrado. São Paulo: FFLCH-USP.

ALBERTI, V.; Pereira, A. A. 2008. Histórias do movimento negro no Brasil: depoimentos ao CPDOC. Rio de Janeiro: Pallas.

ALVES, M. M. 1996. Torturas e torturados. Disponível em <www.marciomoreiraalves.com/downloads/torturas-e-torturados.pdf $>$. Acesso em 05/10/2009.

ALVES, H. L. 1963. Nina Rodrigues e o negro do Brasil. São Paulo: Associação Cultural do Negro.

AMARAL, R. J. 1978. "Roger Bastide: no coração do negro”. Revista do Instituto de Estudos Brasileiros, no 20, p. 126-129.

1991. Os pretos do Rosário de São Paulo: subsídios históricos. São Paulo: João Scortecci.

ANGELO, A.; REIPERT, H. J. 1989. Henrique L. Alves: um agitador cultural. s.l., s.e.

ARRUDA, M. A. N. 2001. Metrópole e cultura: São Paulo no meio século XX. Bauru: Edusc.

BASTIDE, R.; FERNANDES, F. 1955. Brancos e negros em São Paulo. São Paulo: Anhembi.

BASTIDE, R. 1973. "A imprensa negra do estado de São Paulo". In: Estudos afro-brasileiros. São Paulo: Perspectiva.

BASTOS, E. R. 1988. "Um debate sobre a questão do negro no Brasil". São Paulo em Perspectiva, vol. 2, no 2, pp.20-26. 
BARBOSA, M. 1998. Frente Negra Brasileira: depoimentos. São Paulo: Quilombhoje.

BICUDO, V. L. 2010. Atitudes raciais de pretos e mulatos em São Paulo. São Paulo: Editora Sociologia e Política.

CAMARGO, O. 1961. 15 poemas negros. São Paulo: Associação Cultural do Negro.

1972. O carro do êxito: contos. São Paulo: Martins.

1986. A razão da chama: antologia de poesia negra contemporânea.

São Paulo: GRD.

CARDOSO, F. H. 2008. "Uma pesquisa impactante”. In: BASTIDE, R.; FERNANDES, F. Brancos e negros em São Paulo. São Paulo: Global.

CASTRO, C. P. 2010. "Luiz Pereira e sua circunstância: entrevista com José de Souza Martins”. Tempo Social, vol.22, no 1, pp. 239-240.

COSTA PINTO, L. A. 1998. O negro no Rio de Janeiro: relações de raças numa sociedade em mudança. Rio de Janeiro: Ed. UFRJ.

DAMAS, L.G. 1967. Nouvelle Somme de Poésie du Monde Noir. Présence Africaine, n. 57.

DOMINGUES, P. 2007. “Associação Cultural do Negro (1954-1976): um esboço histórico”. Comunicação apresentada no XXIV Simpósio Nacional de História. São Leopoldo: Unisinos.

272 2008. A nova abolição. São Paulo: Selo Negro.

DUARTE, P. 1947a. "Negros do Brasil”. O Estado de São Paulo, 16 abr., p. 5. 1947b. "Negros do Brasil”. O Estado de São Paulo, 17 abr., p.6

FERNANDES, F. 1977. "Em busca de uma sociologia crítica e militante". In: A sociologia no Brasil. Rio de Janeiro: Vozes.

1978. A integração do negro na sociedade de classes. São Paulo: Ática.

2007. "Poesia e sublimação das frustrações raciais". In: O negro no mundo dos brancos. São Paulo: Global.

FERRARA, M. N. 1986. A imprensa negra paulista (1915-1963). São Paulo: FFLCH-USP.

FERREIRA, A. C. 2002. A epopeia bandeirante: letrados, instituições, invenção histórica (1870-1940). São Paulo: Ed. Unesp.

FRIOUX-SALGAS, S. 2009."Présence Africaine, une tribune, un mouvement, un réseau”. Disponível em <http://gradhiva.revues.org/1475>. Acesso em 10/11/2010.

JESUS, C.M. 1960. Quarto de despejo: diário de uma favelada. São Paulo: Francisco Alves.

LEITE, J. C.; CUTI. 1992. ...E disse o velho militante José Correia Leite. São Paulo: Secretaria Municipal de Cultura.

LOFEGO, S. 2004. IV Centenário da cidade de São Paulo: uma cidade entre o passado e o futuro. São Paulo: Annablume. 
MAIO, M. C. 1997. A história do projeto Unesco: estudos raciais e ciências sociais no Brasil. Tese de doutorado. Rio de Janeiro: Iuperj.

MILLIET, S. 1966. "Alguns aspectos da poesia negra”. In: Quatro ensaios. São Paulo: Martins.

MOURA, C. 1983. "Organizações negras”. In: BRANT, V. C; SINGER, P. (orgs.). São Paulo: o povo em movimento. São Paulo: Cebrap.

NASCIMENTO, A. [1968] 1982. O negro revoltado. Rio de Janeiro: Nova Fronteira.

OLIVEIRA, E. 1963. Banzo. São Paulo: Obelisco.

PAULINO, J. 2007. O pensamento sobre a favela em São Paulo: uma história concisa das favelas paulistanas. Dissertação de mestrado. São Paulo: FAU-USP.

PINTO, R. P. 1993. O movimento negro em São Paulo: luta e identidade. Tese de doutorado. São Paulo: FFLCH-USP.

QUINTÃO, A. A. 2002. Irmandades negras: outro espaço de luta e resistência (São Paulo: 1870-1890). São Paulo: Annablume.

SEREZA, H. C. 2005. Florestan: a inteligência militante. São Paulo: Boitempo.

SANTOS, J. F. 2010. Movimento afro-brasileiro pró-libertação de Angola. "Um amplo movimento": relação Brasil e Angola de 1960 a 1975. Dissertação de mestrado. São Paulo: PUC.

SILVA, J. M. F. 1994. Centro de cultura e arte negra: trajetória e consciência étnica. Dissertação de mestrado. São Paulo: PUC.

SILVA, D. M. 2000. A ética da resistência: os exilados antissalazaristas do "Portugal Democrático” (1956-1975). Dissertação de mestrado. Campinas: IFCH-Unicamp.

SILVA, M. A. M. 2010. "Relações entre ativistas negros e sociólogos uspianos, anos 1950 e 1960”. Comunicação apresentada no II Seminário de Sociologia e Política UFPR. Curitiba: UFPR.

2011. A descoberta do insólito: literatura negra e literatura periférica no Brasil (1960-2000). Tese de doutorado. Campinas: IFCH-Unicamp.

VILLA, M. A. 2004. "A destruição de uma biblioteca”. Folha de S. Paulo, 2 jun., p. A3.

VILLAS-BÔAS, G. 2006. "Fazer ciência, fazer história (Guerreiro Ramos, Florestan Fernandes e Costa Pinto)". In: Mudança provocada: passado e futuro no pensamento sociológico brasileiro. Rio de Janeiro: Ed. FGV. 


\section{FAZER HISTÓRIA, FAZER SENTIDO: ASSOCIAÇÃO CULTURAL DO NEGRO (1954-1964)}

MÁRIO AUGUSTO MEDEIROS DA SILVA

Resumo: Discutir-se-ão os anos iniciais de atuação da Associação Cultural do Negro, criada por antigos ativistas e intelectuais da imprensa negra paulistana. Naquele período, ela conseguiu promover ações, jornais, livros e atos públicos visando debater o papel do negro na formação da sociedade brasileira, situando-o num lugar alternativo ao da subalternidade imposta pelo fim da escravidão. Foi apoiada por intelectuais, escritores, sociólogos, ativistas (nacionais e estrangeiros) interessados pelos problemas do grupo negro no Brasil e no continente africano, como Florestan Fernandes, Sérgio Milliet, José Mindlin, Henrique Losinkas Alves, Léon Gontran Damas e os intelectuais da revista Présence Africaine, entre outros. O interesse do artigo é pensar os alcances e limites dessa associação e suas atividades, pouco refletida pela bibliografia conhecida sobre relações raciais e história de movimentos negros no Brasil.

Palavras-Chave: Associação Cultural do Negro; Movimento negro; Relações raciais; São Paulo.

\section{MAKE HISTORY, MAKE SENSE: ASSOCIAÇÃO CULTURAL DO NEGRO (1954-1964)}

Abstract: It will be discussed the initials years of Associação Cultural do Negro, created by olders activists and intelectuals of black press in São Paulo. During that period, it was able to promote actions, newspapers, books and public events aimed at discussing the role of blacks in the Brazilian society formation, placing it in an alternative place of subordination imposed by the end of slavery. It was supported by intellectuals, writers, sociologists, activists interested in the problems of the black group in Brazil and Africa, 
as Florestan Fernandes, Sergio Millet, José Mindlin, Henrique Losinkas Alves, Léon Gontran Damas and intellectuals of the journal Présence Africaine, among others. The interest of the paper is to discuss the scope and limits of this association and its activities, not discussed by the literature on race relations and history of black movements in Brazil.

Keywords: Associação Cultural do Negro; Black movement; Racials relations; São Paulo.

Recebido: 16/05/2011 Aprovado: 31/10/2011 